University of Windsor

Scholarship at UWindsor

\title{
Sound localization and auditory response capabilities in the round goby (Neogobius melanostomus).
}

Audrey Katharina Rollo

University of Windsor

Follow this and additional works at: https://scholar.uwindsor.ca/etd

\section{Recommended Citation}

Rollo, Audrey Katharina, "Sound localization and auditory response capabilities in the round goby (Neogobius melanostomus)." (2005). Electronic Theses and Dissertations. 3540.

https://scholar.uwindsor.ca/etd/3540

This online database contains the full-text of PhD dissertations and Masters' theses of University of Windsor students from 1954 forward. These documents are made available for personal study and research purposes only, in accordance with the Canadian Copyright Act and the Creative Commons license-CC BY-NC-ND (Attribution, Non-Commercial, No Derivative Works). Under this license, works must always be attributed to the copyright holder (original author), cannot be used for any commercial purposes, and may not be altered. Any other use would require the permission of the copyright holder. Students may inquire about withdrawing their dissertation and/or thesis from this database. For additional inquiries, please contact the repository administrator via email (scholarship@uwindsor.ca) or by telephone at 519-253-3000ext. 3208. 


\section{NOTE TO USERS}

This reproduction is the best copy available.

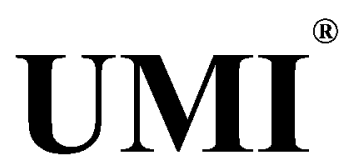




\title{
Sound localization and auditory response capabilities in the round goby (Neogobius melanostomus).
}

By

Audrey Katharina Rollo

\begin{abstract}
A Thesis
Submitted to the Faculty of Graduate Studies and Research through the Department of Biological Sciences in Partial Fulfillment of the Requirements for the Degree of Master in Science at the University of Windsor
\end{abstract}

Windsor, Ontario, Canada

2005

(C) 2005, A.K. Rollo 


$\begin{array}{ll}\begin{array}{l}\text { Library and } \\ \text { Archives Canada }\end{array} & \begin{array}{l}\text { Bibliothèque et } \\ \text { Archives Canada }\end{array} \\ \begin{array}{l}\text { Published Heritage } \\ \text { Branch }\end{array} & \begin{array}{l}\text { Direction du } \\ \text { Patrimoine de l'édition }\end{array} \\ \begin{array}{l}\text { 395 Wellington Street } \\ \text { Ottawa ON K1A ON4 }\end{array} & \begin{array}{l}\text { 395, rue Wellington } \\ \text { Ottawa ON K1A ON4 } \\ \text { Canada }\end{array}\end{array}$

Your file Votre référence ISBN: 0-494-09764-7

Our file Notre référence

ISBN: 0-494-09764-7

NOTICE:

The author has granted a nonexclusive license allowing Library and Archives Canada to reproduce, publish, archive, preserve, conserve, communicate to the public by telecommunication or on the Internet, loan, distribute and sell theses worldwide, for commercial or noncommercial purposes, in microform, paper, electronic and/or any other formats.

The author retains copyright ownership and moral rights in this thesis. Neither the thesis nor substantial extracts from it may be printed or otherwise reproduced without the author's permission.
AVIS:

L'auteur a accordé une licence non exclusive permettant à la Bibliothèque et Archives Canada de reproduire, publier, archiver, sauvegarder, conserver, transmettre au public par télécommunication ou par l'Internet, prêter, distribuer et vendre des thèses partout dans le monde, à des fins commerciales ou autres, sur support microforme, papier, électronique et/ou autres formats.

L'auteur conserve la propriété du droit d'auteur et des droits moraux qui protège cette thèse. $\mathrm{Ni}$ la thèse ni des extraits substantiels de celle-ci ne doivent être imprimés ou autrement reproduits sans son autorisation.
In compliance with the Canadian

Privacy Act some supporting forms may have been removed from this thesis.

While these forms may be included in the document page count, their removal does not represent any loss of content from the thesis.
Conformément à la loi canadienne sur la protection de la vie privée, quelques formulaires secondaires ont été enlevés de cette thèse.

Bien que ces formulaires aient inclus dans la pagination, il n'y aura aucun contenu manquant.

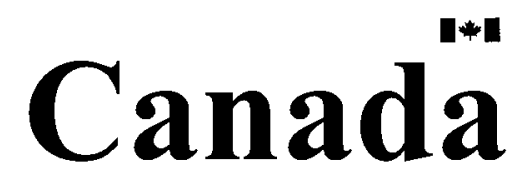




$$
1027273
$$

\begin{abstract}
:
A fundamental role of vertebrate auditory systems is determining the direction of a sound source. While fish show directional responses to sound, sound localization remains in dispute. Determining directionality is the ability to distinguish between the left or right side, while localization is being able to determine where in space the origin is. The species used in the current study, Neogobius melanostomus (round goby) uses sound in reproductive contexts, with both male and female gobies showing directed movement towards a calling male. A two-choice laboratory experiment was used (active versus quiet speaker) to analyze behaviour of gobies in response to sound stimuli. When conspecific male spawning sounds were played, gobies moved in a direct path to the active speaker, suggesting true localization to sound. Of the animals that responded to conspecific sounds, $85 \%$ of the females and $66 \%$ of the males moved directly to the sound source. Auditory playback of natural and synthetic sounds showed differential behavioural specificity. Of gobies that responded, $89 \%$ were attracted to the speaker playing Italian goby (Padogobius martensii) sounds, $87 \%$ to a $100 \mathrm{~Hz}$ tone burst, $62 \%$ to white noise, and $56 \%$ to black goby (Gobius niger) sounds. During the round goby call, swimming speed to the playing speaker was doubled, and the angle standard deviation was two times more direct than during any other sound playback. Results suggest a strong localization of the round goby to a sound source, with some differential sound specificity. This research is the first to explicitly quantify the ability of a fish to localize a sound source.
\end{abstract}




\section{Acknowledgements}

Thanks most of all to my Mom, Dad, and Rob for all of your love and support.

Dennis - I am very honoured to be the first out of what will be a long list of graduate students to come out of your lab. I wanted to dedicate this thesis to you, because of your encouragement I decided to go to grad school. You are the best advisor a grad student tould ask for, and a good friend. Thanks for all of your positive words, and your unwavering help. You are the smartest person I know....

Higgs Lab.....what can I say, the unofficial motto fits $(:)$....Gotta love an all female lab (somehow you fit in there Rumi). Andrea, best of luck for finishing school quick and I can't wait to see the new baby. Thanks for being a good friend, I will miss the serenades. Kristen...I definitely see lots of papers coming out from you. Keep up all your hard work and don't let things get to you. Kirsten, good luck with the upcoming school year...if anyone can get first year into shape it's you! Eva, thanks for taking care of the lab and keeping us on our toes! Rumi....the best one was the kids and the guy at the window...raggae style, also the kid on the street with the dog. Maria, to sum it up; ...Scottish accents, obscenities at the Detroit Science Center, and Vancouver craziness.

Misun...great times! What am I going to do without you!! You are a wonderful person and I am sure I will see you again...shyness. Christine, if anything good came out of TA'ing first year; it was meeting you....slices, cuties, casino, cuties, dancing, cuties. Thanks for always listening. Camilo, you made me want to be better, thanks for inspiring me. Carla, you've always being there for me - you are a great friend! Chelsey and Yakuta, we are the graduate sisters. It was nice to go through the last crazy month with you two...and then the celebrationssssss. () I am so glad I met everyone here...I will miss you all very much!!

Sarah and Tori....you two are such good friends. You kept me sane through a lot of madness; I will always cherish our long, late night phone calls. I am so thankful that the boyz brought us together.

Thanks to all the graduate students from Bio, GLIER, and Earth Sciences, and all of the faculty and staff at the University, Nancy your the best.

Last but not least, puppy and Jade for your unconditional cuteness. 


\section{Table of Contents}

Abstract................................................................ iii

Acknowledgments............................................................. iv

List of Figures................................................................... vi

Chapter One Introduction.....................................................1

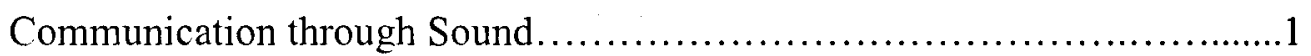

Sound in Reproduction..................................................

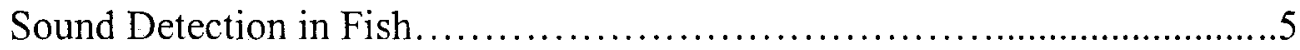

Directionality in Fish.................................................. 17

Round Goby....................................................... 20

Thesis Overview and Significance............................................ 26

Chapter Two Introduction...................................................27

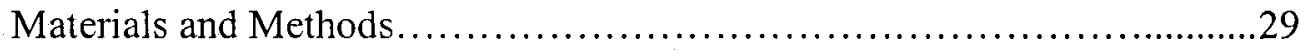

Housing Conditions........................................................29

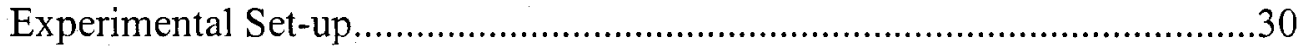

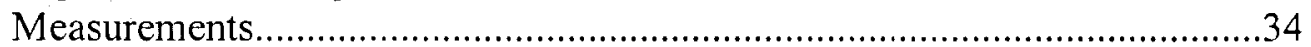

Statistical Analysis....................................................

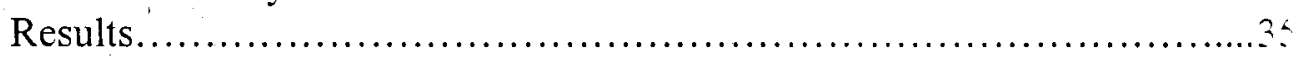

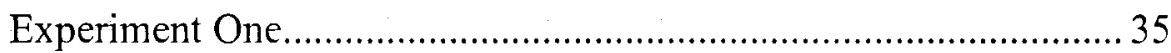

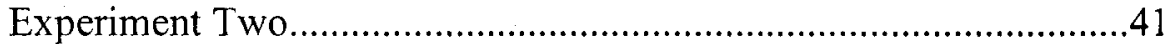

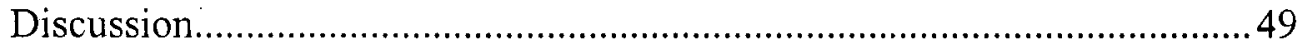

Appendix A: Standard deviation and average angles in experiment.......................54

Appendix B: Standard deviation and average velocity in experiment one..............55

Appendix C: Activity of round gobies during experiment two...........................56

Appendix D: Standard deviation and average velocity during experiment two......58

Appendix E: Standard deviation and average angle during experiment two.......... 60

Appendix F: Experimental tank acoustics.................................................62

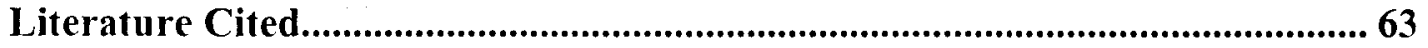

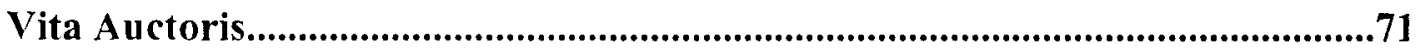




\section{List of Figures}

Figure 1: Ear and brain of a fish...........................................

Figure 2: Otolith and hair cells....................................... 8

Figure 3: Sensory hair cells with the ciliary bundle $\ldots \ldots \ldots \ldots \ldots \ldots \ldots \ldots \ldots \ldots \ldots$

Figure 4: Body and head lateral lines................................... 11

Figure 5: Lateral line canal with cupula....................................... 13

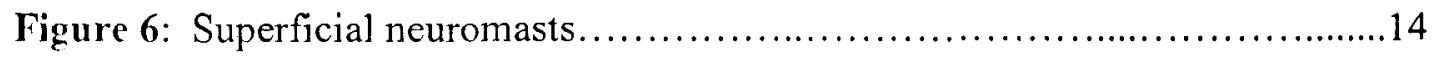

Figure 7: Weberian ossicles......................................... 16

Figure 8: Directional sensitivity of a hair cell............................. 19

Figure 9: Hair cell orientations...................................... 21

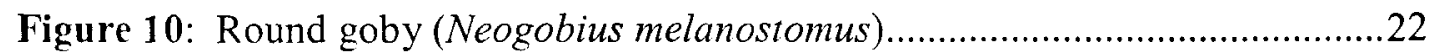

Figure 11: Experimental Tank set-up..................................... 31

Figure 12: Urogenital papillae of round goby.............................. 32

Figure 13: Movement of the round goby in experiment one................... 37

Figure 14: Destination of round goby in experiment onc................................... 38

Figure 15: Average angle of the round goby in experiment one......................... 39

Figure 16: Velocity of round goby, experiment one..........................40

Figure 17: Destination of round goby movement in experiment two....................42

Figure 18: Round Goby proximity to playing speaker in experiment two............. 43

Figure 19: Round goby average velocity for experiment two............................ 45

Figure 20: Round goby standard deviation in velocity for experiment two........... 46

Figure 21: Round goby average angle for experiment two............................. 47

Figure 22: Round goby standard deviation in angle for experiment two.............. 48 


\section{Chapter One Introduction}

\section{Communication through Sound}

The ability to communicate, through sounds or body language, is essential to pass along information to other individuals. Sounds can be produced in a variety of ways in animals. The most recognized way to produce sound is through vocal cords (like in many vertebrates), but sound can also be generated by using other parts of the body. Feral horses, Equus caballus, will stomp their foot to show aggression (Cameron et al 2003), while some birds, such as neotropical manakins (Aves: Pipridae), produce sounds by rubbing their wings or tail feathers together to attract a mate (Prum 1998). Underwater sound is essential for relaying messages to others when water visibility is limited. Hence the variability in sound producing mechanisms in aquatic animals is quite large. Snapping shrimp (Symalpheus parneomeris) are the largest source of sound in the coastal ocean, producing very loud broadband sounds by snapping their claws and cavitating water (Au and Banks 1998). One of the effects of the snapping is to stun or kill prey animals. When startled or frightened, Asian redtail catfish (Hemibagrus wyckioides) emit a loud squeak by pressing out air from their gill slits (Heyd and Pfeiffer 2000). Soundproducing mechanisms in male cichlids (Tramitichromis intermedius) involve sound generation by the pharyngeal mill, amplified by the swim bladder (Lobel 2001). Adult croaking gouramis (Trichopsis vittatus) generate sounds by beating their pectoral fins against their body (Henglmuller and Ladich 1999). Even though the variation in sound producing mechanisms is vast, the type of functions for which 
sound is used is more conserved. Several species are known to produce apparent warning, alarm, or escape sounds when prodded or attacked (Heyd 2000; Amorim 2004). In the study by Heyd (2000), $1000-4000 \mathrm{~Hz}$ sounds (frequencies above the hearing range of most fish) were produced from catfish when taken out of the water by predaceous fishing mammals and birds, which are able to detect these high frequencies. These sounds are thought to be made to warn the predator that the food they just caught will not be an easy meal (the pectoral and dorsal spines on the catfish are erected simultaneously, with locking mechanisms, when the fish is removed from the water). These warning sounds are very similar to the chat of rattlesnakes which caution nearby animals of its poisonous bite. Sound is also produced during, territorial defence (Myrberg 1997; Johnson 2000). Kenyon (1994) showed male bicolour damselfish, Pomacentrus partitus, exhibiting courtship sounds, a 'chirp' and a grunt. The chirp occurs at the beginning of courting and the 'grunt' just prior to spawning. Male competitors would travel towards spawning sounds only during the grunt phase. The intentions of the competitor damselfish would likely be to interfere with the imminent spawning or to gain a possible spawning partner. Pupfish, Cyprinodon bifasciatus, have territorial boundaries which they patrol. Calls are produced by males during pursuits of nearby fish, while the pupfish follows a female, as well as just after spawning (Johnson 2000). Amorim et al (2004) showed grey gurnard (Eutrigla gurnardus) produce sounds during competitive feeding. These grunts warn of the forager's presence to nearby competitors, deterring other fish from gaining access to disputed food items. The ability of a fish to communicate 
effectively within its environment, regardless of the variability in the sound producing methods, is essential for survival.

\section{Sound in Reproduction}

Acoustic displays are not only important as a warning or alarm sound, but in a reproductive context as well. Mate competition and choice are two phases of the reproductive process in which fish can use sound to demonstrate their physical condition. Sound can indicate if the fish is suitable for reproduction, an attractant for the opposite sex, or if the fish is primed to copulate. Differences in sound amplitude and pulse rate could reveal a fish's body size (Ladich 1988; Lindström 1992; Malavasi et al 2003), which could be important for mate recognition and choice. Lindström (1992) studied male sand gobies (Pomatoschistus minutes) and found that body size often correlated with sound pressure levels, since acoustic pulses are generated by specialised sonic muscles (Demski et al. 1973), and the mass of these muscles increases with increasing body size (Lindström 1992). It can then be assumed that the larger the sonic muscle the bigger the fish, resulting in a deeper sound emitted from larger sand gobies. Rowe and Hutchings (2004) also looked at the sonic muscles, but in Atlantic cod (Gadus morhua). This study found that males had drumming muscles that were larger than females, which increased in mass prior to spawning and declined subsequently. Drumming muscle mass of spawning males was also positively associated with body size, condition, and fertilization potential, suggesting that sound production may be an indicator of the size of the signaller and may reveal information about individual quality. The cavity-nesting darters 
Etheostoma nigripinne and Etheostoma crossopterum also produce sounds associated with reproduction (Johnston and Johnson 2000). Males produce sounds during aggressive encounters and courtship activities, categorized as drums, knocks, and purrs. Sounds associated with aggressive encounters could indicate to a female that the fish is a strong defender of its territory, and would be more of a quality mate. Sound production indicating size of a mate during the spawning season has fitness benefits, perhaps through a role in mate competition.

Sound can also indicate, to potential mates, if another fish is ready to mate. Sound production rate has been shown to increase with reproduction, especially in fish that form spawning aggregations (Saucier and Baltz 1993; Finstad 2004). This relationship is largely due to increases in courtship calling rather than production of specific spawning sounds. Hawkins (2000) studied the haddock (Melanogrammus aeglefinus) and showed male fish produce a series of 'knocking' sounds during the spawning season. The male initially produces a short series of slowly repeated 'knocks' until the sounds becomes longer and faster (coinciding with an increase in arousal of the male). It is suggested that these sounds piay a role in synchronising the reproductive behaviour of the male and female (Hawkins 2000). Some sounds are thought to attract the female to the spawning area (McKibben and Bass 1998). Lugli et al. (1995) found the freshwater Italian goby (Padogobius martensii) emits 'drumming' sounds to lure females into the nest.

Sound used to demonstrate viability as a mate. as well as an attractant to reproduce, is also used to synchronize copulation. Hypoplectrus unicolor, a coral reef fish, 
produces sound prior to, or simultaneously with, gamete release into the water (Lobel 1992). This could be an acoustic signal to its mate to ensure synchronous gamete release. In the East African Rift Lake cichlid fish, Tramitichromis intermedius, only the male emits sound during courtship (Ripley and Lobel 2004). Sound is intentionally used to communicate that the male cichlid is ready to spawn, with the first sound emission coinciding with the first courtship activity (quivering), and spawning occurring just days later. Thus the ability to produce sound and perform quiver behaviour simultaneously could also be a measure of mate quality. Primed for reproduction, weakly electric mormyrid fish (Pollimyrus isidori) migrate from tributaries into shallow (2-3 m) flood plains during the flooding season (Crawford et al 1997). Male sound production is stimulated by the presence of the females, comprised of grunts and moans during the night. Fishes' ability to recognize a sound pattern is necessary to pick up cues when and with whom to mate, ensuring the survival of a community of fish.

\section{Sound Detection in Fish}

Producing sound would have no context if the organism was not capable of receiving the information. Thus, hearing is an integral part of understanding the environment, and consequently propagating a species. There are two physical properties of sound, particle motion and sound pressure. Sound can generate particle motion and sound pressure in the near field, but as the sound wave travels, the motion dissipates more quickly in the far fjeld displaying only pressure (Braun and Coombs 2000). The near field is defined as the region of space close to a sound source, whereas far field is the 
region where the radial distance from the sound source is much greater than a wavelength (Rogers and Cox 1988). Lateral line neuromasts' (cupular organs) respond to near field effects with frequencies up to about $200 \mathrm{~Hz}$ (Braun and Coombs 2000). Fish should be able to determine the direction of a sound source in the near field by comparing responses of different cupular organs. Sound pressure effects are dominant at higher frequencies and at increasing distance from the fish. Detection of near-field vibrations can thus occur using both the ear and the lateral lines, but only in close proximity to the sound source. Far-field waves travel long distances in water, the inner ears of fish detect these sound waves.

Like other vertebrates, fish have inner ears located near the brain enabling the fish to hear (Figure 1). However, unlike mammals, the cochlea and the tympanic membrane (eardrum) are not present, and the ear does not open to the outside of the body. Instead, the sensory hair cells, located inside the ear, are stimulated by otoliths (tiny calcareous structures) and detect sound (Figure 2). There are six otoliths, each within the three sets of auditory organs; the saccule, lagena, and utricle. In most fishes, the saccule is thought to be primarily an auditory organ, playing important roles in directional hearing and frequency responses ( $\mathrm{Lu}$ and $\mathrm{Xu} 2002$ ). The lagena is still unknown as to its role in hearing (although in the goldfish the lagena responds with great sensitivity to acoustical particle motion) (Fay 1995). Traditionally the utricle has been considered a vestibular organ, however Lu et al (2004) has shown that the utricle in the sleeper goby (Dormitator latifrons) plays an auditory role in azimuth (horizontal) directionality and that the directional hearing response dynamic range is 


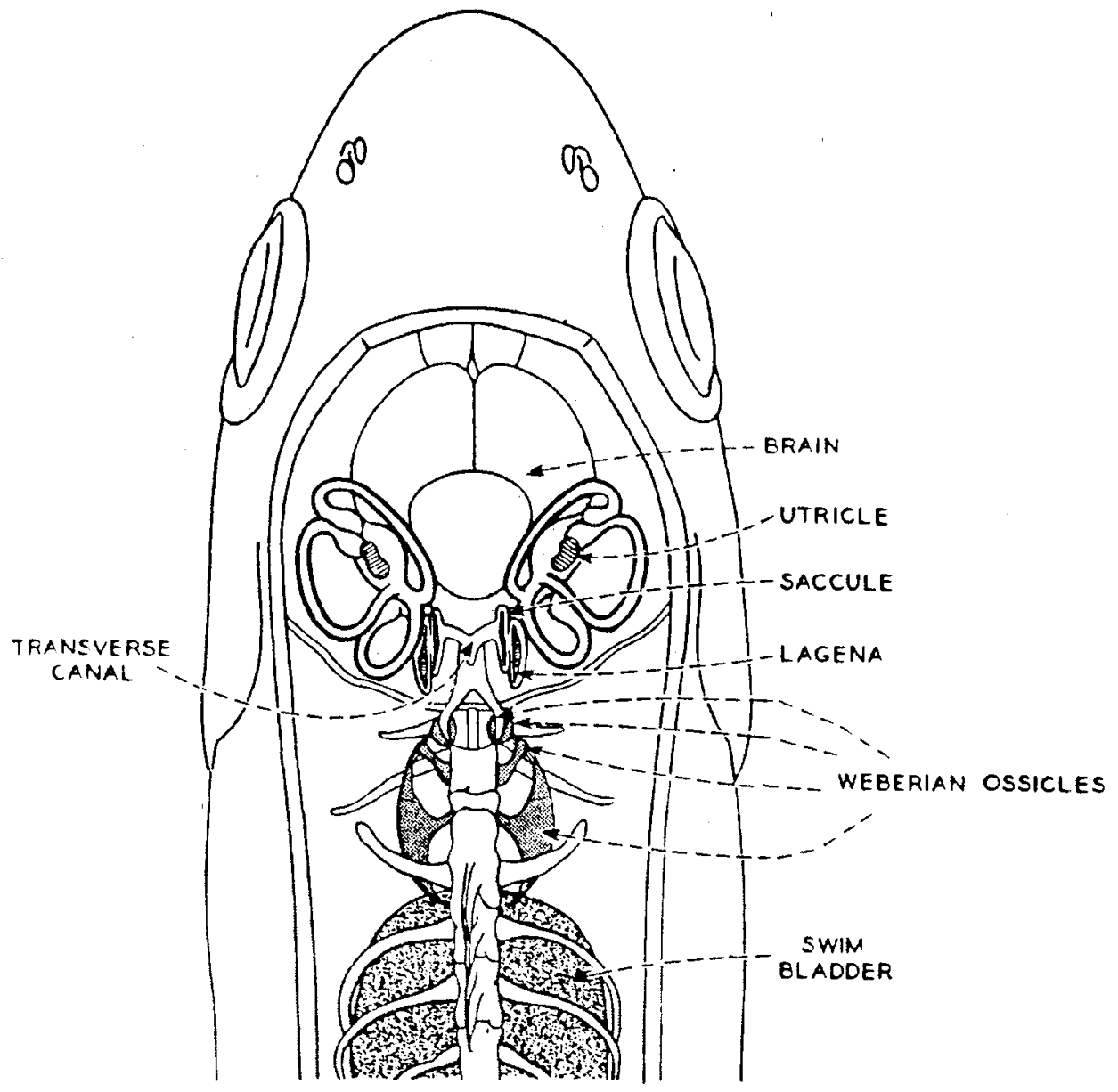

Figure 1: Location of the ear and brain in a fish head. Labelled parts of the ear; saccule, lagena, and utricle. Weberian ossicles not found in all fish. Figure modified from Fay and Feng 1987. 


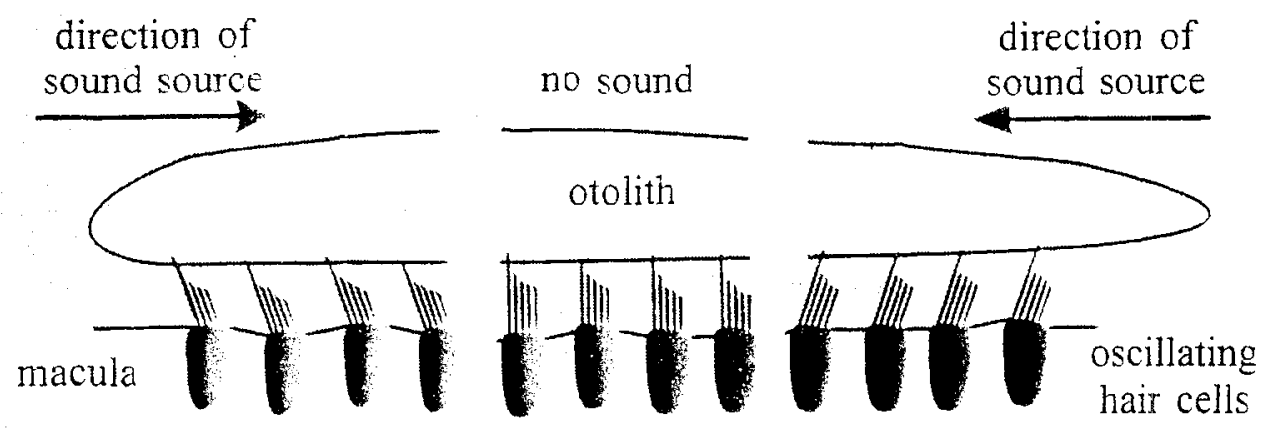

Figure 2: Schematic drawing of the otolith above the hair cells. Depending on the direction of the sound source (indicated by arrows), the macula will move relative to the otolith, causing the hair cells to bend. This displacement is relayed to the brain, indicating the direction of the sound. Figure modified from Lu and Popper 2000. 
extended by the utricular organ. Sound detection occurs when acoustic vibrations in the water are conducted through the skeleton of the head to the inner ears, causing a stimulation of the hair cells relative to the lagging otolith. Hair cells are extended epithelial cells with a ciliary bundle located apically (Figure 3 ). The ciliary bundle is composed of stereocilia, graded in size with the longest next to a single kinocilium. An acoustical wave passes through the flesh of a fish undisturbed (since it has the same density as the surrounding water) until it reaches the more dense otolith, this causes the hair cells (attached to the otolith) to bend in that direction. If the hair cell movement is in the direction of the kinocilium, the hair cell membrane potential will result in a depolarization (Schellart and Popper 1992). Displacement, or movement, of the stereocilia in the opposite direction of the kinocilium causes hyperpolarization. Thus, the cells' response is determined by the amplitude of stereociliary deflection along a single axis. This sends a signal to the brain with information about the sound source.

In addition to the ears in a fish, sound is also detected through the lateral line system (Figure 4). The mechanosensory lateral line system of fish is used to detect water motion (relative to the surface of the animal) and mediates such varied behaviours as prey detection, predator avoidance, hydrodynamic imaging, rheotaxis, schooling, and courtship communication (Coombs and Montgomery 1999). The lateral line system, which runs along the sides of the head and body, contains mechanoreceptors that detect movement by a mechanism similar to the function of those in the inner ear. In most fish, the lateral line system has two types of receptors: canal neuromasts and superficial neuromasts. Canal neuromasts lie within canals located beneath the skin 
OTOLITH

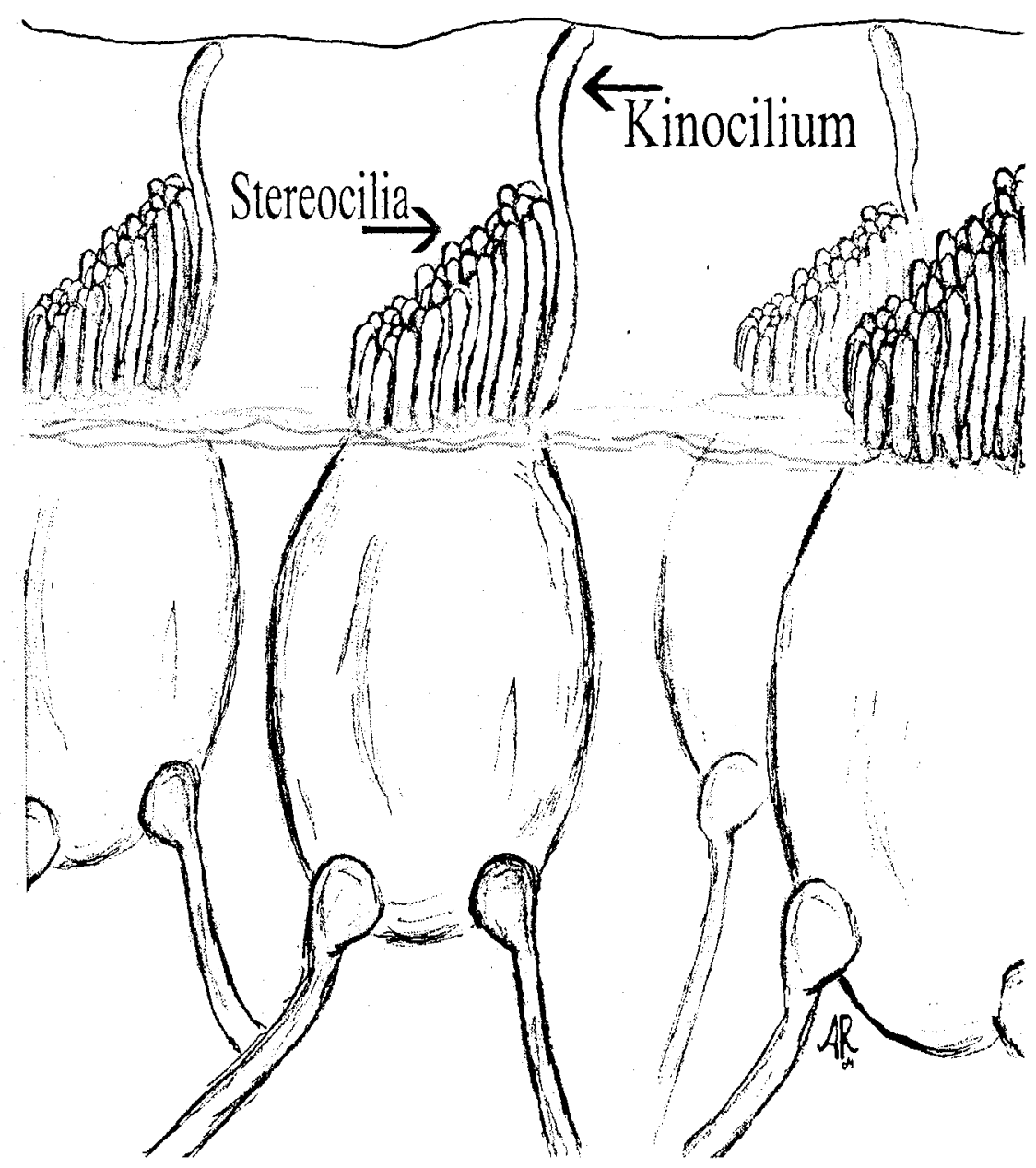

Figure 3: Schematic drawing of sensory hair cells with the ciliary bundle showing the stereocilia and kinocilia at the apical surface. 


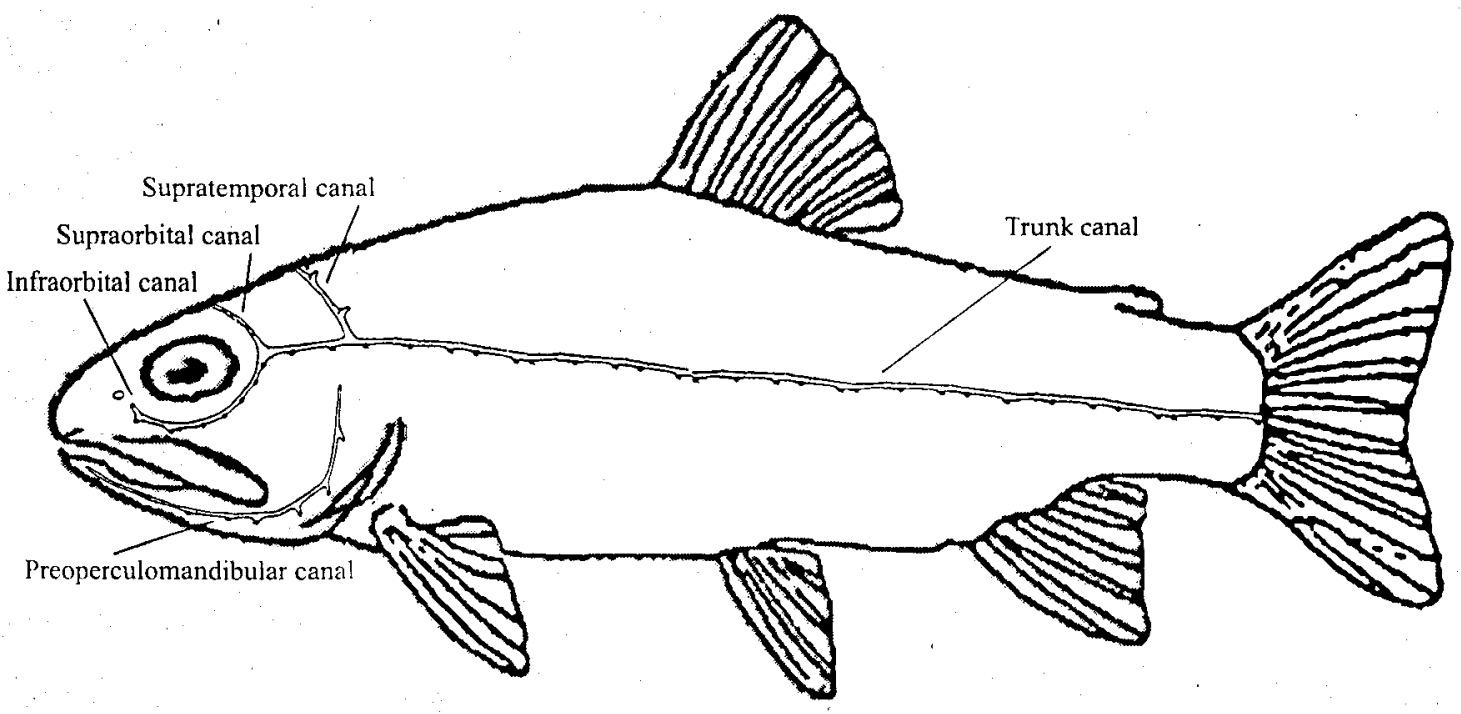

Figure 4: Drawing of the lateral line canal system on a generalized fish body and head. 
surface, filled with a fluid slightly more viscous than the surrounding water. Small pores from the canals allow any disturbances in the water around the fish to be transferred to the canal fluid, past mechanoreceptors which are all along the tube. These receptors (neuromasts) each have a cluster of hair cells, with the sensory hairs embedded in a gelatinous cap (cupula) sensitive to water acceleration (Figure 5) (Denton and Gray 1982). As the displacement of the moving water bends the cupula, the hair cells transduce the energy into action potentials that are transmitted to the brain. Canal hair cell orientations are typically in opposite direction of each other so one of them will respond best to water flow in one direction in the canal, where the other to water flow in the opposite direction (Coombs et al 1995). In comparison, superficial, or free, neuromasts are found on the skin surface, usually in several specific locations, and typically aligned in rows on the body and head (Figure 6). In superficial neuromasts, the cupula responds largely to the velocity of water flowing past it (Denton and Gray 1982). Water sliding past the cupula generates drag causing the cupula to bend. Thus the degree of bending is directly related to water velocity. The lateral line greatly expands the tactile area of perception, by allowing the fish to interpret its environment without actually touching an object.

Sound is also detected through the air-filled chambers (e.g. the swim bladder) in fish. The chambers vibrate, translating pressure of the sound wave into displacement information which is then transmitted to the inner car. In some fish, sound pressure sensitivity is high and the fish is able to detect a broad range of frequencies due to the presence of hearing specializations creating an indirect pathway to the ears. Fish with 


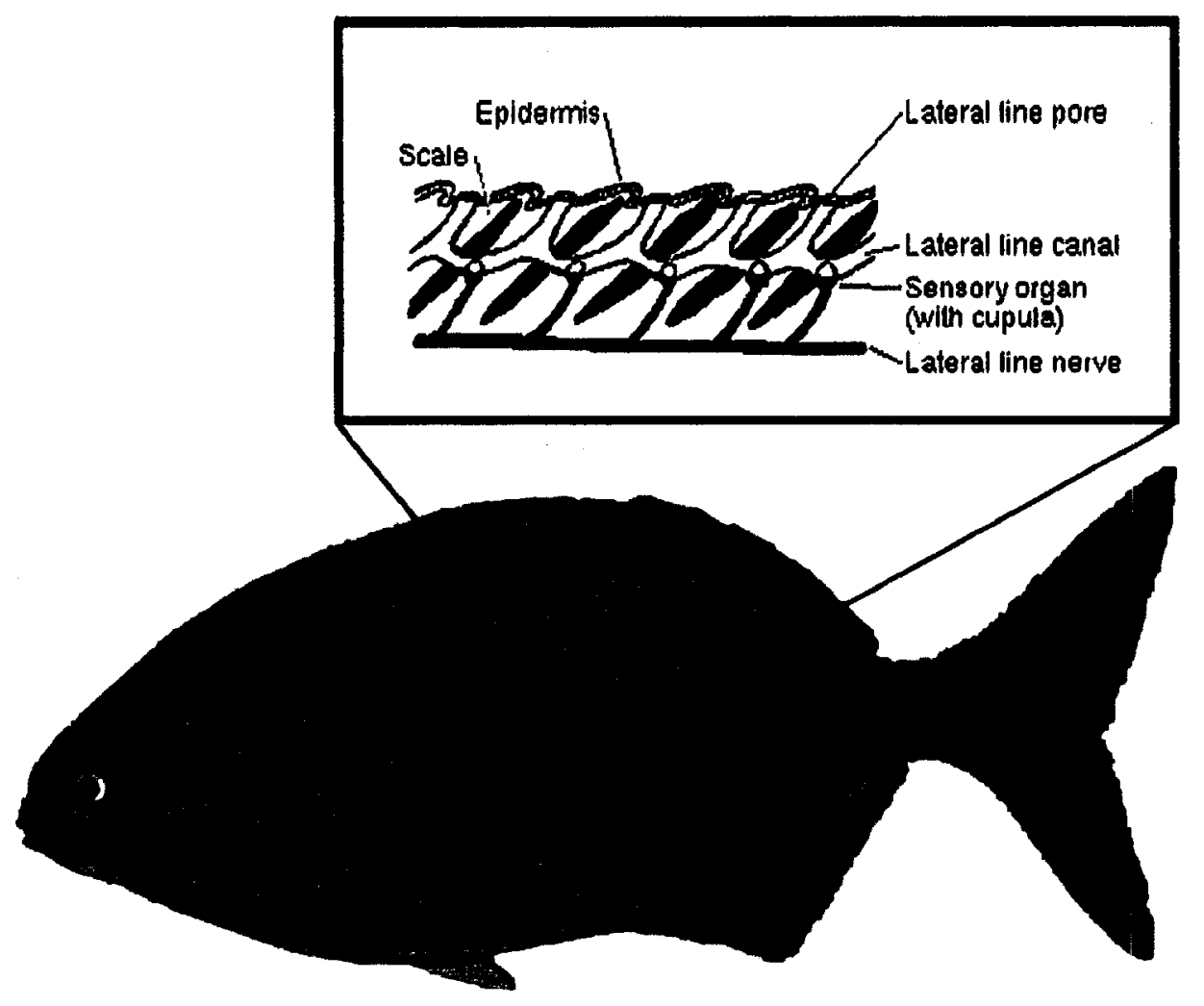

Figure 5: Schematic drawing of the cupula located in the lateral line canal. As water moves past the neuromasts (located in the cupula) information is sent through the lateral line nerve to the brain regarding displacement direction. Brassy sea chub (Kyphosus vaigiensis) photo modified from Richard Field. Drawing modified from Dijkgraaf 1962. 


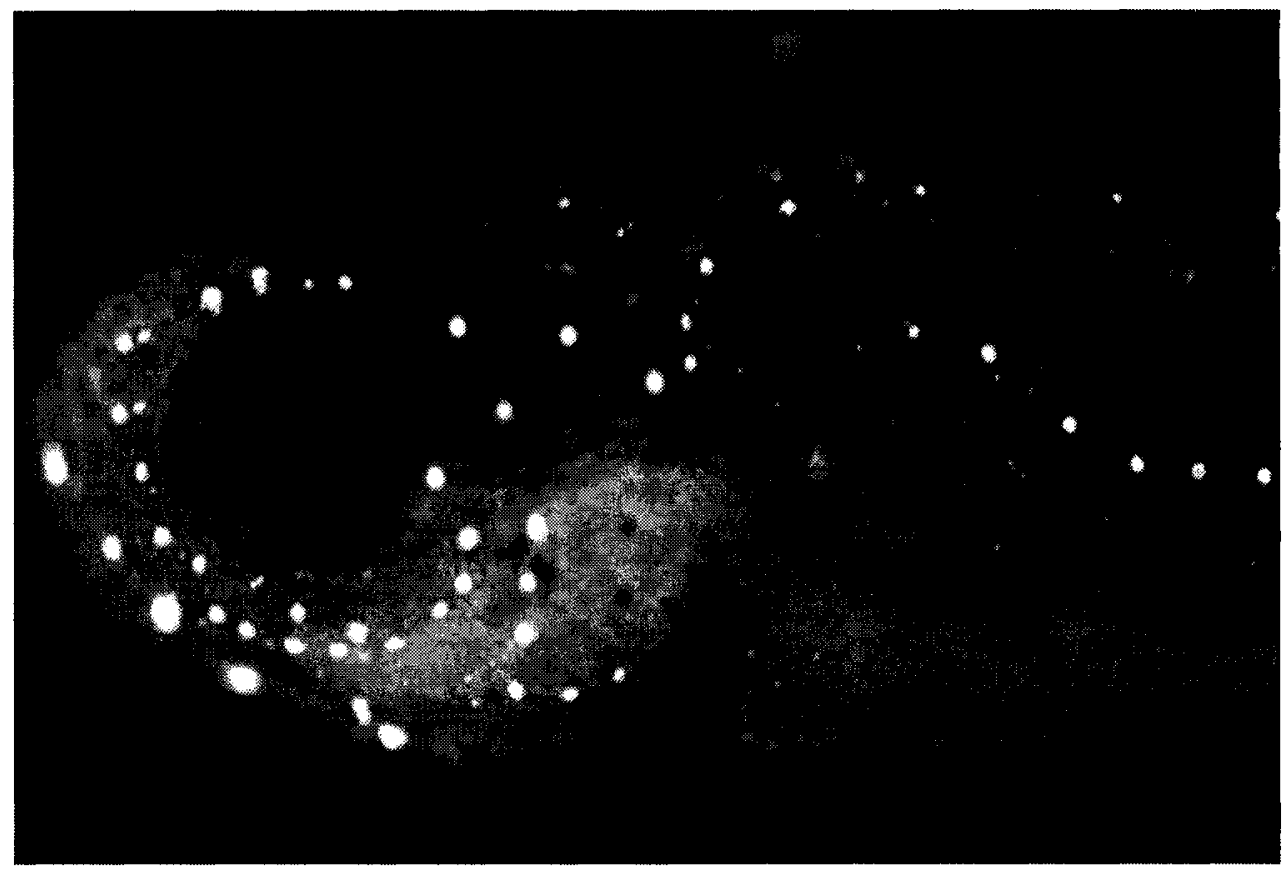

Figure 6: Superficial neuromasts (white dots in picture) located on the body and head of a zebrafish (Danio rerio), demonstrates general spatial distribution of neuromasts in fish. Neuromasts were stained with the fluorescent dye DASPEI, which selectively stains highly active cells. Fish total length (for scaling purposes) is approximately $10 \mathrm{~cm}$ 
these adaptations are termed "hearing specialists" (Popper and Coombs 1982; Ramcharitar et al 2004). Catfish and minnows have a series of bones called Weberian ossicles connecting the swim bladder to the inner ear directly (Von Frisch, 1938; Chardon and Vandewalle 1997) (Figure 7). These bones enable the fish to hear higher frequencies than non-specialists. Carassius auratus (goldfish) are the most studied hearing specialists and can detect sound up to $5000 \mathrm{~Hz}$ (Kenyon et al. 1998). Other specialists, such as the squirrelfish Myripristis kuntee has the swim bladder directly contacting the ear (Popper 1977). Another type of hearing specialist adaptation is found in the mormyrids, with an auxiliary air bubble attached to the saccule (Stepetic 1939). In at least two groups of teleosts the utricle is associated with specializations for hearing (Popper and Tavolga 1981; Higgs et al 2004). For example, the marine catfish (Arius felis) is an otophysan species with an acute hearing at $\sim 200 \mathrm{~Hz}$, where other otophysans hear best from 500 to $1000 \mathrm{~Hz}$. This is due to the fact that Arius has an enlarged utricle with hair cells only along the striolar region (Popper and Tavolga, 1981). Clupeomorph fishes have an air-filled auditory bulla associated with the utricle (Denton and Gray, 1979; Best and Gray, 1980). This specialization in the utricle and associated structures may be the reason why clupeids in the subfamily Alosinae can detect ultrasound up to $180 \mathrm{kHz}$ (Mann et al 1997, 1998, Higgs et al 2004). Fish that have narrower frequency ranges with higher auditory thresholds (and no auditory specializations) are termed "hearing generalists". Hearing generalists do not detect frequencies above $800 \mathrm{~Hz}$ and tend to have higher auditory thresholds. Hearing generalists, such as the oscar (Astronotus ocellatus), can hear frequencies between $100 \mathrm{~Hz}$ and $2000 \mathrm{~Hz}$ (Lu et al 1996). Smith et al (2004) 


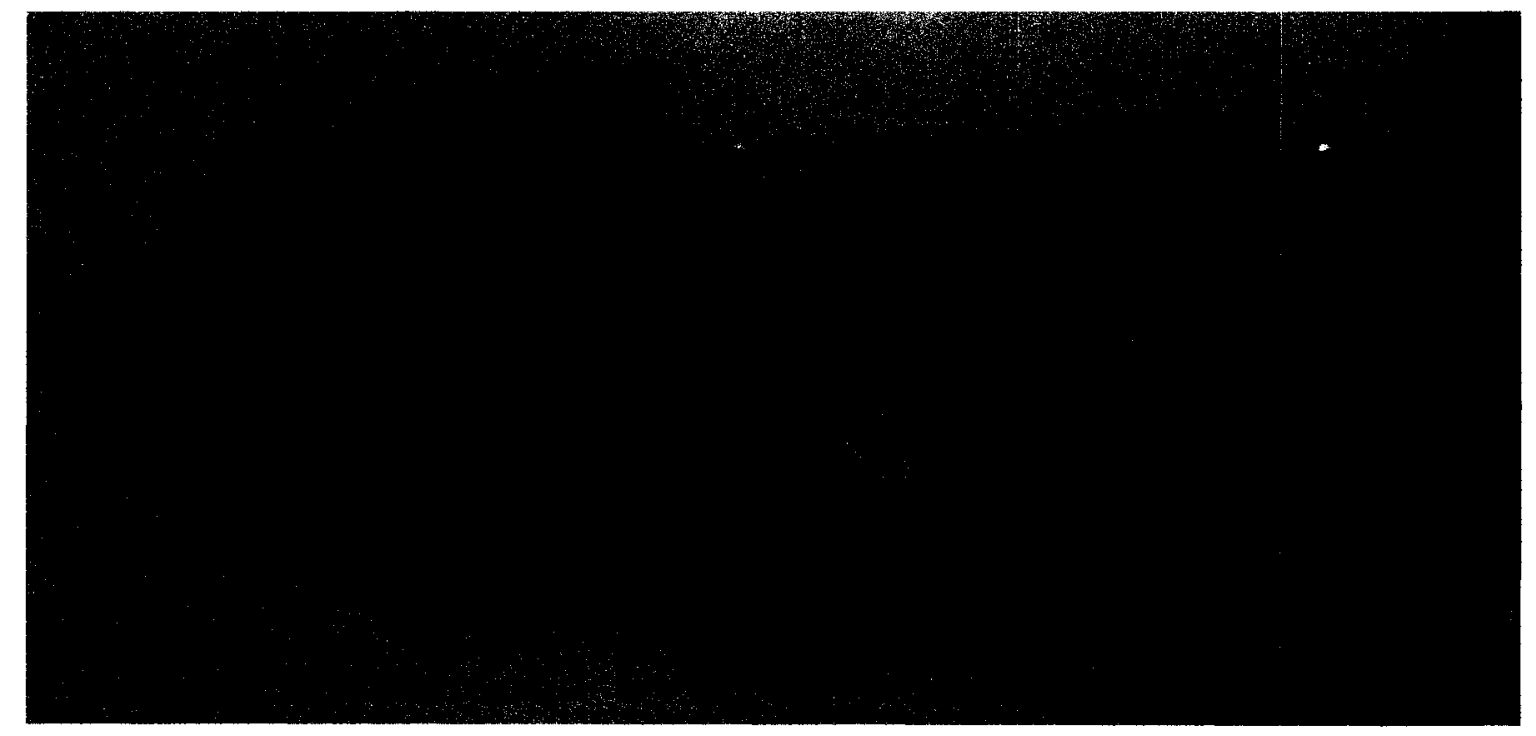

Figure 7: Orientation of the Weberian ossicles in a zebrafish, linking the swim bladder and ear. Weberian ossicles (indicated by the arrow) are stained using standard cleaning and staining techniques (see Higgs 2003). 
showed that tilapia (Oreochromis niloticus), a hearing generalist, was less susceptible to noise sound pressure levels than goldfish, a hearing specialist. This lower susceptibility was due to the tilapia's higher auditory threshold levels, where the goldfish was more sensitive to the higher frequencies. This shift in linear threshold relationship shows the divergence in susceptibility between hearing specialist and generalist fishes.

\section{Directionality in Fish}

Aquatic sound detection presents certain problems not normally encountered by terrestrial organisms. Humans and other land animals can perceive spatial localization which is the ability to discern azimuth or horizontal (left-right) directionality and zenith or vertical (up-down) directionality (Sabin et al 2005). This directionality can be perceived using localization cues such as Interaural Time Difference (ITD) (Hancock and Delgutte 2004) and Interaural Intensity Difference (IID) (Oswald et al 1999). The Interaural Time Difference (ITD) is the difference in arrival time of a sound to each ear, sounds coming from the left or right will arrive at the corresponding ear first. Although the delay time differences are slight, the brain can extract precise directional information from this data. The head, as well as shoulders and upper torso, form a barrier to a sound's arrival at one ear or the other. This creates an acoustical shadow and an effect called the Interaural Intensity Difference (IID) (Schleich et al 2004). The effect of the shadow is frequency dependent; high frequency sounds are more attenuated than low frequency sounds because low frequencies can bend around obstructions and are not as easily blocked. 
For example, this is the reason high frequency information in a complex waveform is more readily perceived at the incident ear--this relative difference in resonance is yet another cue used to determine directionality. Given that sound speed in water is about five times higher than that in air, and the distances between the two ears in fish are generally no more than a few centimetres, fish cannot use interaural time, phase, and intensity differences of sound pressure to localize a sound source (Fay and Feng 1987). Current models of fish hearing assume fish determine the direction of incident sound through otolith motion along the direction of the acoustic wave (de Vries 1950; Fay 1984; Lu et al. 1996). The complex geometry of fish otoliths may help to distinguish flow patterns for sound from different directions (Popper and Coombs 1982).

The ears of fishes are stimulated by otolith motion, either directly (from the water medium to tissue and bone) or indirectly (by sound pressure from the swim bladder or other gas bubble near the ears). When sound energy is transmitted to the ears directly, the body of the fish takes up the sound's acoustic particle motion, and hair cell stimulation occurs due to the difference in inertia between the hair cells and their overlying otoliths. When the sound pathway to the ears is indirect, the swim bladder or gas bubble near the ears expands and contracts in volume in response to sound pressure fluctuations, and this motion may be transmitted to the otoliths. Fishes tend to respond to and encode the directionality of pressure gradients using both the ears and lateral line (Fay 1984; Lu and Popper 1997). Sensory hair cells are morphologically and physiologically polarized so that their response to hair bundle movement is proportional to a cosine function of the direction of stimulation relative 


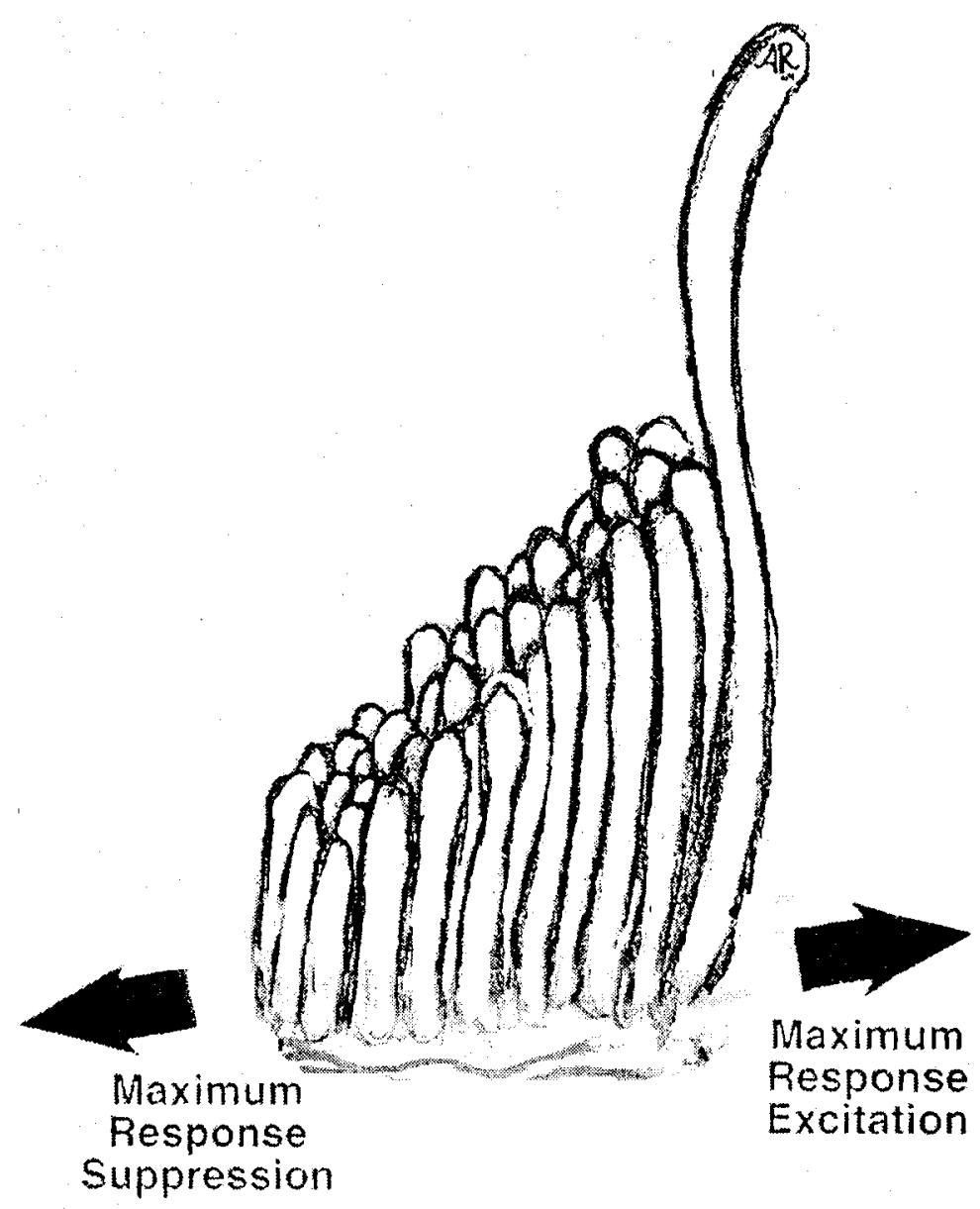

Figure 8: Directional sensitivity of a hair cell. The membrane potential varies with the cosine of the angle between the direction of maximum sensitivity and the applied displacement. 
to the most sensitive axis of the cell (Hudspeth and Corey 1977) (Figure 8). This axis is defined as a line from the center of the hair bundle through the kinocilium. Since hair cell groups on the epithelia are oriented in different directions as well as having complex patterns, they may function in directional hearing (Figure 9). Many sensory epithelia have a complex curvature, increasing the range of stimulus directions possible. Plus, each end organ in an ear, as well as corresponding organs of the two ears, orient on nonparallel planes. So fish can potentially obtain a good deal of directional information by comparing separate hair cell inputs from both ears, as well as from all of the end organs (Wubbles et al. 1993). Localization acuity could be ascertained in two kinds of experiments; 180 degree discrimination (where the fish would choose in which direction to orient) or a measure of the smallest angle between the two sources (allowing the animal to discriminate between them). Schuijf (1975) showed cod's (Gadus morhua) ability to orient towards a sound source under free field conditions. Cod can also discriminate between sources separated by $10-20$ degrees in azimuth (with a high signal level), as well as sources from opposing directions $\left(180^{\circ}\right.$ apart) in both the horizontal and vertical planes (Schuijf and Buwalda 1975).

\section{Round Goby}

The species used in the current studies was the round goby (Neogobius melanostomus) (Figure 10). Round gobies are demersal and prefer shallow, brackish waters, but can also be found in freshwater and marine habitats with a depth range of $0-30 \mathrm{~m}$. They are eurythermal, tolerating temperature ranges of 0 to $30^{\circ} \mathrm{C}$, but mainly thrive in 


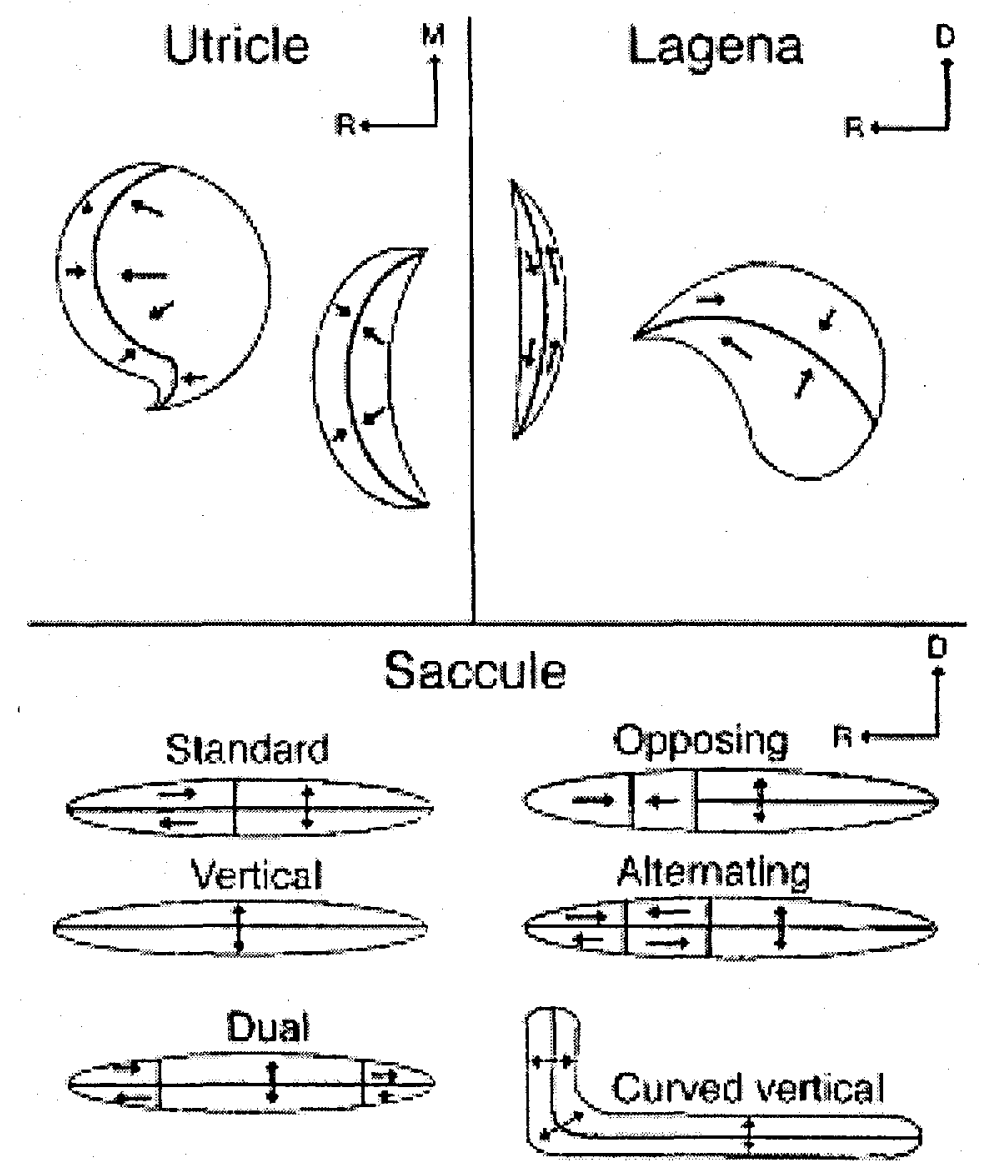

Figure 9: Schematic drawings of various hair cell orientations in fish. ** These patterns represent the majority of fish that have been studied. The arrows indicate the orientation of the hair cells (with respect to the location of the kinocilium) in each epithelial region. Figure from Popper and Fay 1999. 


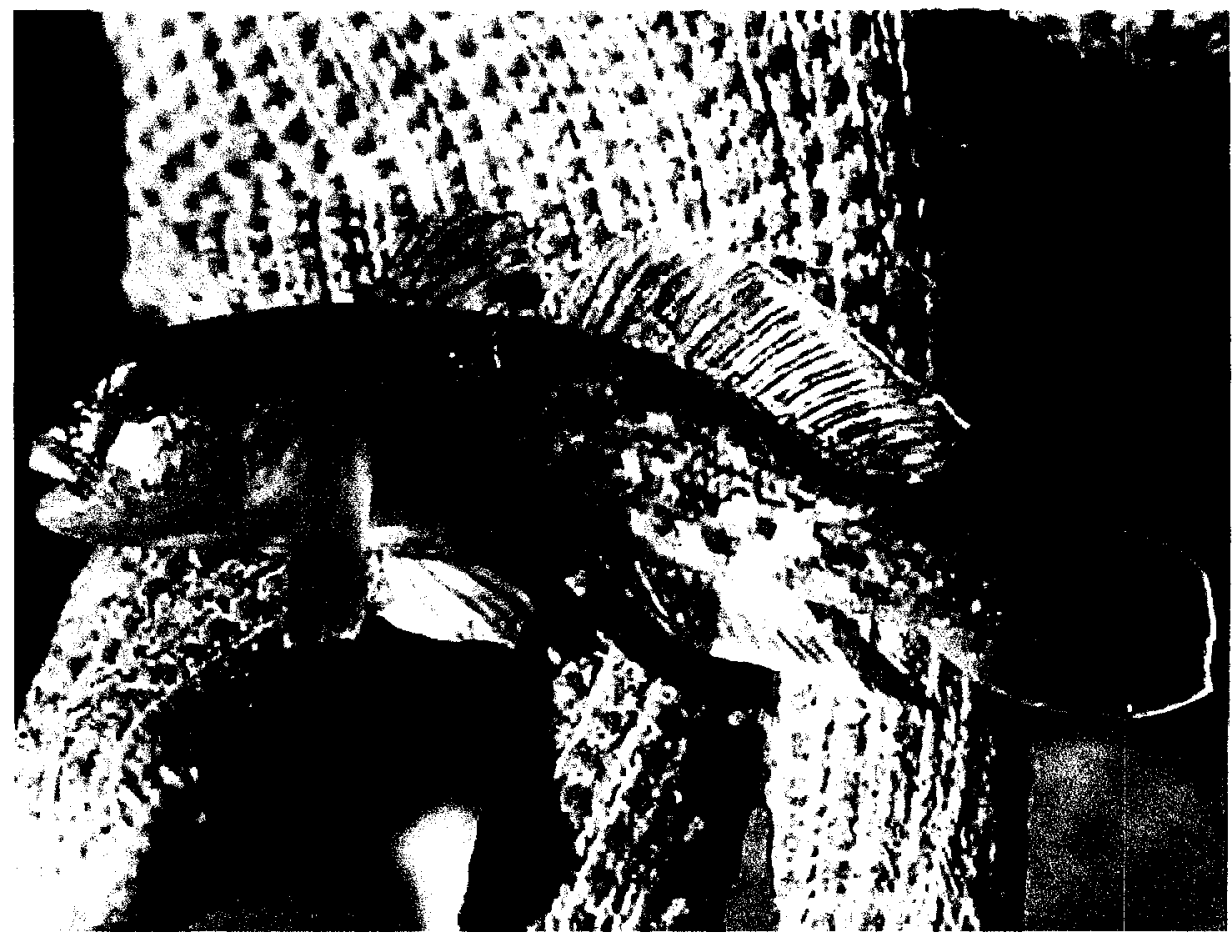

Figure 10: Round goby (Neogobius melanostomus). Photo from Dave Jude, Michigan Sea Grant. 
warm temperate waters (Kottelat 1997). Round gobies are aggressive, voracious feeders with the ability to forage in total darkness (Dubs and Corkum 1996). Distribution originated in Europe (Sea of Azov, Black Sea and Caspian basins), however several countries (such as Canada and the United States) have reported an introduction of round gobies (via contaminated ballast water of transoceanic ships) with adverse ecological impact resulting (Vanderploeg et al 2002). The round goby is considered a pest in the Great Lakes Basin because they take over prime spawning and habitat sites traditionally used by native species, such as lake trout, Salvelinus namaycush (Chotkowski \& Marsden 1999), lake sturgeon, Acipenser fulvescens (Nichols et al. 2003), and smallmouth bass, Micropterus dolomieu (Steinhart et al. 2004). Native fish recruitment is also affected due to the round gobies multiple spawning habits (up to six times a year), and high fecundity (Corkum et al 2004). Round gobies are even thought to reduce the quality of the water, by transferring energy and contaminants from the benthos to higher trophic levels (Morrison et al. 2000). Even though the mechanism for sound production in round gobies has not been studied, other gobies emit sound by expelling pressurized water out of their gills and snapping their jaw (Lugli et al 2004). Round gobies are known to produce several vocalizations, emitted by the male either attracting a female to the nest site or intimidates other males from entering their territory (Protasov et al. 1965). Sound detection in the round goby results from otolith displacement and through the lateral line, since they do not have a swim bladder. Even though round gobies lack a trunk canal, superficial neuromasts are on their body and head, with additional canal neuromasts in the head canals (Jude and DeBoe 1996). The presence of superficial 
neuromasts on the body may enable the round goby to detect prey with more sensitivity than species where the body neuromasts lie within a canal.

The round goby was chosen for the current studies due to its sexually dimorphic behaviour, as well as for its abundance and easy collection. Sexual dimorphism can be seen in fish in a variety of attributes which can include behaviour and external morphology. External morphological features can consist of coloration, size differences, and sexual organs, whereas sexually dimorphic behaviour is expressed as different behaviours in opposite sexes of the same species. Corkum (2004) has shown the round goby respond aggressively in the presence of conspecific odours. When an odour is presented in an established male tank, the male reacts strongly and aggressively to the site where the odour was emitted. It has also been shown that the introduction of a large round goby to a weaker or smaller gobies shelter will induce a flight reaction in the smaller goby (Stammler \& Corkum 2005). Although sexually dimorphic behaviour to acoustical sounds has not been investigated in the round goby, studies have successfully shown Gobiidae species (as well as other fish species) react to auditory cues. Male sand gobies (Pomatoschistus minutus) produce sounds (consisting of a repeated train of pulses) when a female enters a nest before spawning (Lindström and Lugli 2000). The acoustic parameters of sand gobies indicate a possible role of sound in mate choice. Frillfin gobies (Bathygobius soporator) exhibit sexually dimorphic bchaviour, with body movement and a change in appcarance (Tavolga 195̦6). 
The current thesis project focuses on the localization abilities of round gobies to conspecific spawning cues and the possible sound specificity gobies have to other sound sources. Auditory playback of natural and synthetic sounds showed differential behavioural specificity. Results suggest a strong localization of the round goby to a sound source, with some differential sound specificity. 


\section{Thesis Overview and Significance}

This study quantifies sound localization in fish and their specificity to sound (including conspecific, heterospecific, and computer generated sounds). Behavioural analysis of the round goby to sound is beneficial in implementing possible capture methods of the fish as well as comprehending basic auditory processing in fish. This invasive, voracious fish threatens the ecosystem of the Great Lakes, through its consumption of larval native fish, out competing adult native fish spawning sites and food resources, and may ultimately cause a large monetary loss. The round gobies ability to localize sound could prove valuable in designing lure traps enticing them with a conspecific spawning sound. The ability of fish to localize sound is still highly debated in science; this research study is the first to explicitly quantify the ability of a fish to localize a sound source. 


\section{Chapter Two Introduction}

The ability to use sound for communication is essential to pass along information to other individuals. The ability to localize that sound is probably one of the most functional aspects of the auditory system. Determining the direction of a sound could aid in, to name only a few; prey detection, predator or object avoidance, locating a potential mate. Like other vertebrates, fish have inner ears located near the brain enabling the fish to hear. However, unlike mammals, the cochlea and the tympanic membrane (eardrum) are not present, and the ear does not open to the outside of the body. Terrestrial vertebrates perform localization through a combination of interaural time and intensity differences (Hancock and Delgutte 2004, Oswald et al 1999). Although the delay time differences are slight, the brain can extract precise directional information from this data. Given that sound speed in water is about five times higher than that in air, and the distances between the two ears in fish are generally no more than a few centimetres, fish cannot use interaural time, phase, and intensity differences of sound pressure to localize a sound source (Fay and Feng 1987). These facts fuel the debates regarding the ability of fish to localize a sound source. One could argue that directional hearing underwater would be impossible because of the physical properties of a wavelength and the lack of interaural time between the two ears and yet some studies have shown fish can find sound sources readily (Schuijf 1975; McKibben and Bass 1998; Tolimieri et al. 2000).

Current models of fish hearing assume fish determine the direction of incident sound through otolith motion along the direction of the acoustic wave (de Vries 1950; Fay 
1984; Lu et al. 1996). The complex geometry of fish otoliths may help to dịstinguish sound flow patterns from different directions (Popper and Coombs 1982). Behavioural research studies, such as Schuijf (1975), show cod (Gadus morhua) have the ability to orient towards a sound source under free field conditions. Cod can also discriminate between sources separated by $10-20$ degrees in azimuth (with a high signal level), as well as sources from opposing directions $\left(180^{\circ}\right.$ apart) in both the horizontal and vertical planes (Schuijf and Buwalda 1975). Field studies have shown fish are able to localize sound. Tolimieri et al (2000) found higher concentrations of fish larvae in light traps with sound sources than light traps with out sound. Lu and Popper (2001) show fish localize sound from the morphological polarity of hair cells that otolithic afferent neurons innervate. This enables fish to encode directional information about a sound source (predominantly in elevation). McKibben and Bass (1998) show female midshipman fish (Porichthys notatus) respond selectively to audible sounds and are capable of differentiating between acoustic signals (duration, frequency, amplitude, and spectral/temporal content).

The current project focuses on the localization abilities of round gobies to conspecific spawning cues and the possible sound specificity gobies have to other sound sources. Prior hypotheses on sound localization in fish have suggested localization is accomplished by the phase difference between particle motion detected by the hair cells directly and sound pressure reradiated from the swim bladder (Schuif, 1975). The species used in the current study, round goby (Neogobius melanostomus) has no swim bladder or other obvious hearing specializations and yet it uses sound for reproductive communication (Protasov et al. 1965). Thus sound detection results 
from otolith displacement and through the lateral line. The round goby was also selected due to its possible sexually dimorphic behaviour, as well as for its abundance and easy collection. Although sexually dimorphic behaviour to acoustical sounds has not been investigated in the round goby, studies have successfully shown Gobiidae species (as well as other fish species) react to auditory cues (Tavolga 1956, Lindström and Lugli 2000). The current study used playback of natural sounds (round goby, black goby ((Gobius niger $))$, and Italian goby ((Padogobius martensii)) spawning sounds) and synthetic sounds ( $100 \mathrm{hz}$ and white noise), to examine differential behavioural specificity and acoustic localization in free-swimming round gobies.

\section{Materials and Methods}

\section{Housing Conditions}

Fish used in these experiments were collected by angling at different shoreline sites from the Detroit River and Lake Erie. At collection, the goby was unhooked and placed into a large bucket filled with water from the area. After angling 10 to 20 gobies (time frame 30 to 60 minutes), the bucket containing the gobies was transported to the lab, approximately $15-30$ minutes away. In the laboratory, the gobies were housed temporarily in the transport container equipped with an air-stone, until transferred to the experiment tank. Temporary housing conditions follow University of Windsor Animal Care procedures. 


\section{Experimental Set-up}

Behavioural experiments were conducted in a 1020 litre rectangle tank with dechlorinated tap water (water depth $=33 \mathrm{~cm}$ ). At one end of the tank were two underwater speakers (UW-30, Universal Sound Inc), connected to an amplifier (Alesis RA300), which was in turn connected to a Toshiba laptop computer. One speaker was designated the "active" speaker (playing the experimental sounds) and one the "quiet" speaker (no sound being played). The order of presentation alternated between the two speakers and the speakers were $25.5 \mathrm{~cm}$ apart. The tank was bisected by a mesh net, $107 \mathrm{~cm}$ from the speakers to allow placement of the goby at a defined distance from the speaker while reducing reflections off the back of the tank. To begin an experiment, one goby was placed into the experimental tank, along the mesh partition (Figure 11). The experimental sound started immediately afterward. No acclimation period was given because gobies were only responsive for a limited time (about 2 hours) once brought into the laboratory. The decibel level of the sound stimulus (as measured by a precalibrated hydrophone, Interocean Inc) in the experimental tank varied slightly dependent on sound stimulus presented, specific ranges are below. When a response was observed from the goby, or ten minutes had expired, the experiment ended. The goby was then removed and placed into an aquarium with a filter and air-stone. Sex was ascertained by examination of the urogenital papillae at the end of the trial (Figure 12). The female urogenital papillae are broad and blunt, 0.3-0.5 mm long and 0.2-0.4 mm wide (Miller 1984). The male papillae are somewhat longer, with a length of 0.3-0.6 mm and a terminal slit. Gobies were used only once during the experiment. 


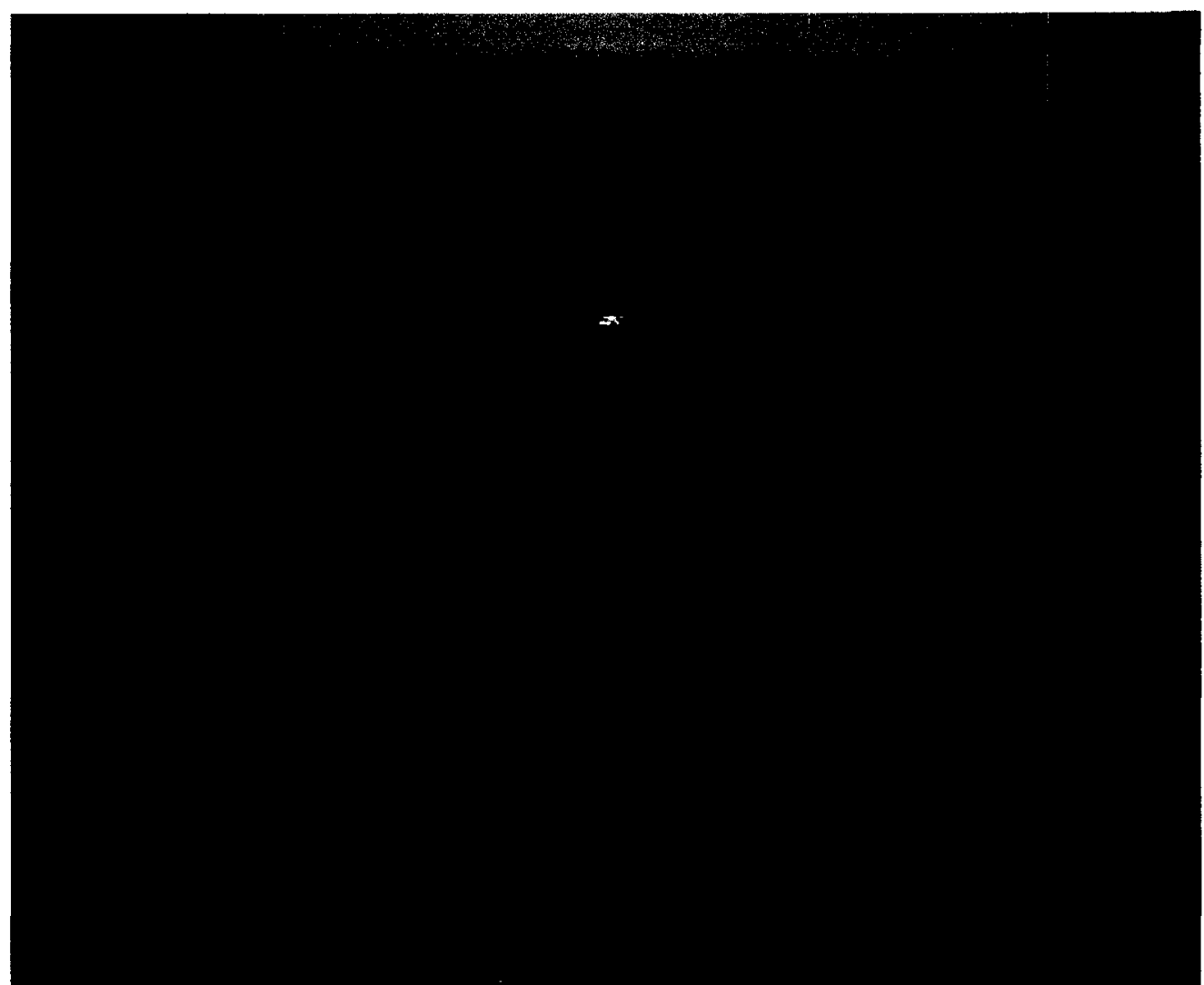

Figure 11: Experimental tank set-up. Goby is placed next to net (bottom of picture) in the center of the tank. Sound was played from one of the speakers at the top of the tank. Distance between the net and the speaker is $107 \mathrm{~cm}$. 


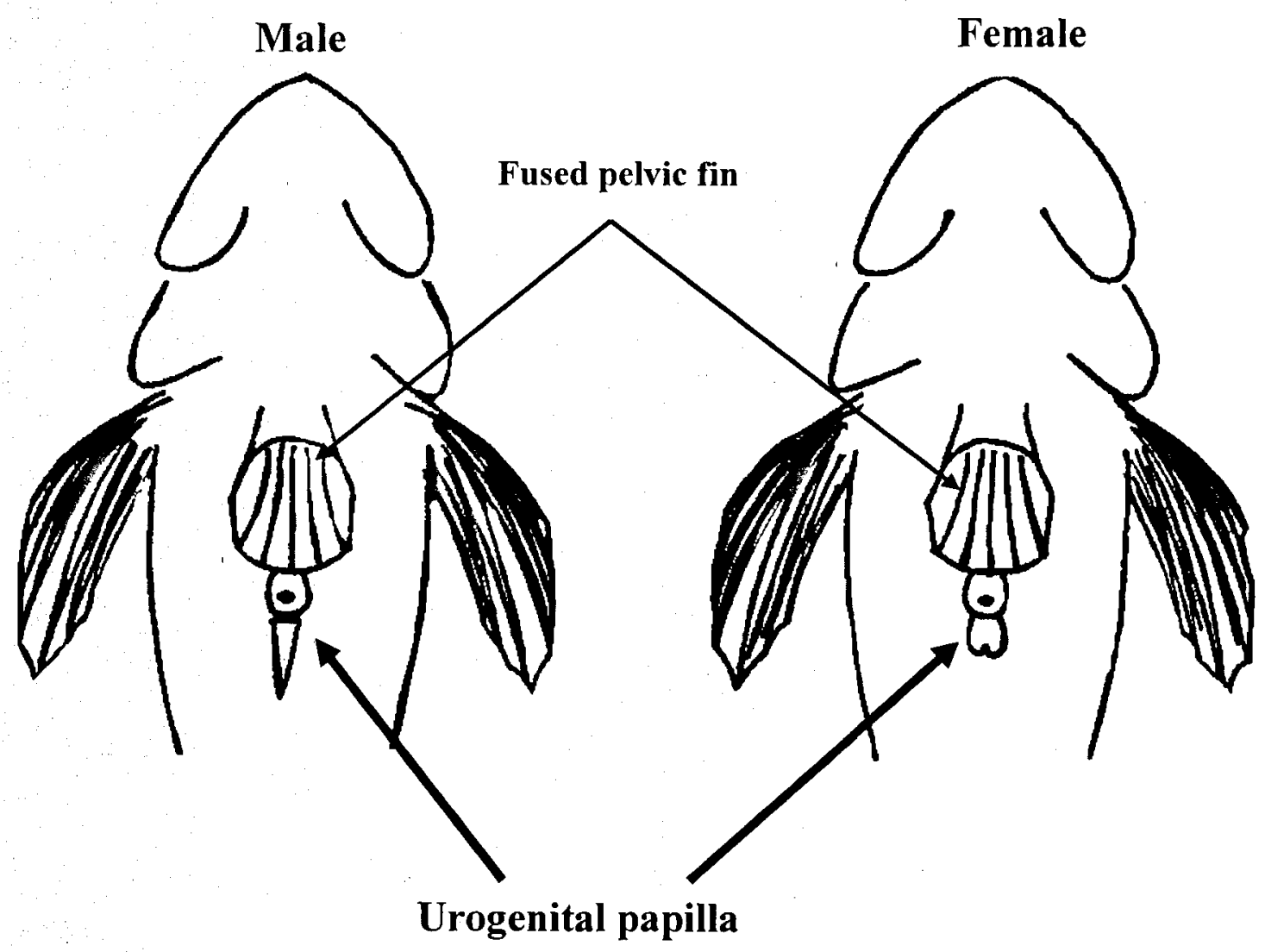

Figure 12: Urogenital papillae of male and female round goby (modified from Charlebois et al. 1997). 
Two sets of experiments were performed, in which behaviour, swimming speed, and approach angle were measured in both. Gobies in the first set of experiments (experiment 1) were exposed to a male round goby spawning sound. The sound was recorded in a natural environment by John Janssen and Greg Androsso. A total of 137 round gobies were collected, during the months of July to September, 2004. Of the 137 fish tested 79 were males and 58 were females. The second experiment (experiment 2) had five sounds individually played during different trials. The sounds included vocalizations of round goby, black goby (Gobius niger), and Italian goby (Padogobius martensii), as well as computer generated $100 \mathrm{~Hz}$ tone bursts and white noise. Sound levels played were $138-141 \mathrm{~dB}$ re $1 \mu \mathrm{Pa}$ for the round goby, 132$140 \mathrm{~dB}$ re $1 \mu \mathrm{Pa}$ black goby, $138-140 \mathrm{~dB}$ re $1 \mu \mathrm{Pa}$ for the Italian goby, $144 \mathrm{~dB}$ re $1 \mu \mathrm{Pa}$ for the $100 \mathrm{~Hz}$ tone, and $136 \mathrm{~dB}$ re $1 \mu \mathrm{Pa}$ for white noise (136dB re $1 \mu \mathrm{Pa})$. Tank acoustics gradually decreased in $\mathrm{dB}$ from speaker to net (Appendix F). Control experiments had no sound. Experimental sounds were also played with a geophone (Geospace LP, sensitivity $19 \mathrm{mV}$ per $\mathrm{mm}$ ) positioned at the location of goby release in the tank to examine the amount of substrate vibration during playback. At no point did the geophone detect vibrations above background levels (1.5 $\mathrm{dB}$ re $1 \mu \mathrm{Pa})$. Italian goby courtship sounds were provided by Marco Lugli (University of Parma, Italy) and black goby calls were obtained from fishbase (www.fishbase.org). The $100 \mathrm{~Hz}$ tone burst is similar to the fundamental frequency of the round goby call $(168 \mathrm{~Hz})$ whereas white noise encompasses all of the frequencies in the spectrum. Control experiments were run with the goby in a quiet tank (no speaker playing sounds). For the control trials, the amplifier was unplugged from the speakers to eliminate any 
possibility of static or buzzing noise. A total of 120 round gobies were used for experiment two, 20 gobies per sound. No goby was used for more than one trial.

\section{Measurements}

Trials were recorded with a Sony Digital Handycam camcorder (model DCRTRV27), then digitized and analyzed using Peak Motus Version 7.0 software. The camcorder was positioned on a tripod over the tank and recorded the behavioural responses of the goby to the sound stimuli. Reaction to the experimental conditions was quantified in terms of the percent of gobies that responded to each sound, which speaker the goby approached, how close to the speaker the goby came, and the speed, average angle, and path deviation at which an approaching goby moved. For percent responding, a goby was recorded as "responding" if it made any movement during the sound presentation. This behaviour was further subdivided into movement to the active speaker, movement to the quiet speaker, or non-directed movement in the tank. Of those fish that showed directed movement to the playing speaker, the nearest approach distance was recorded and subsequently grouped as movement within 10 $\mathrm{cm}$ of the active speaker, or stopping $10-13 \mathrm{~cm}$ away from the playing speaker, $13-18$ $\mathrm{cm}$ away from the playing speaker, and $18-30 \mathrm{~cm}$ away from the playing speaker. Captured images were digitized and analyzed by Peak Motus Version 7.0. For those fish that responded, velocity, mean path angle to the speaker, and the standard deviation in path angle were recorded. For mean path angle, the angle determined by the Peak Motus program had to be manually corrected for fish position at the start of a trial. A mean corrected angle of $90^{\circ}$ indicated a direct heading toward the active speaker. For simplicities sake, when referring to particular sounds, the notation in the 
parenthesis will be used. The sounds used in experiment two were; black goby Gobius niger (B), Italian goby Padogobius martensii (I), round goby Neogobius melanostomus (R), $100 \mathrm{~Hz}$ tone $(\mathrm{T})$, white noise (W), silent tank/absence of sound (S).

\section{Statistical Analysis}

All raw data (sex, sound, and activity), plus data from Peak Motus, were imputed into Microsoft Excel and Systat 10. Data in Excel calculated averages between velocity, angle, and sex of gobies, plus standard deviation of angles and velocity. A two sampled t-test (assuming equal variances) was used to compare sexes to find if there was any variation between them. A Chi square test was performed on the movement to sound between sexes, determining if there was significance in activity within a sex. Systat performed a two-way analysis of variance (ANOVA), between sex and sound type, independent variables, with speed and angle, the dependent variables. If the ANOVA results were significant, Tukey tests compared all the sounds individually and determined which sound was statistically significant.

\section{Results}

\section{Experiment One}

When the male round goby spawning sound was played in experiment one $37 \%$ of the males moved in the tank and $51 \%$ of the females moved in the tank (Figure 13). No significant difference $(\mathrm{P}=0.63)$ was found in the percent of fish responding to sound between sexes. Of the fish that responded during the trials, three behaviours were 
observed: fish that moved toward the playing speaker, fish that moved toward the silent speaker, or fish that moved to neither one of the speakers. When the gobies moved during the trial, $85 \%$ of the females, and $66 \%$ of the males, moved towards the playing speaker (Figure 14). When movement was observed to the silent speaker, $9 \%$ of the responding fish were females and $31 \%$ males. Non-directed movement was also observed, with $6 \%$ and $3 \%$ (female and males respectively), defined as moving less than $30 \mathrm{~cm}$ from the starting position.

The average angle to the playing speaker for the round goby in experiment 1 was $89.2^{\circ}$ (with a straight path defined as $90^{\circ}$ ). Females traveled on average $87.4^{\circ}$ to the playing speaker, with males moving $90.7^{\circ}$ towards the speaker (Figure 15). There was no significant difference between average angle in females and males $(P=0.60)$. Refer to Appendix A for individual average angles. The standard deviation in approach angle for the round goby females was $7.4^{\circ}$, males $12.0^{\circ}$. There was no significant difference between average angle in females and males $(P=0.25)$. Refer to Appendix A for individual standard deviation angles. When speed was averaged for females and males, females traveled $13.1 \mathrm{~cm} / \mathrm{sec}$ to the playing speaker, whereas males traveled $19.5 \mathrm{~cm} / \mathrm{sec}$ (Figure 16). A significant difference was found between sexes $(P=0.04)$, with males traveling much faster to the playing speaker than females. Appendix B has the itemized listing of speed. There was no significant difference in standard deviation of speed for males versus females $(P=0.12)$. Females had a variation standard deviation of $5.7 \mathrm{~cm} / \mathrm{sec}$, males $8.6 \mathrm{~cm} / \mathrm{sec}$. 


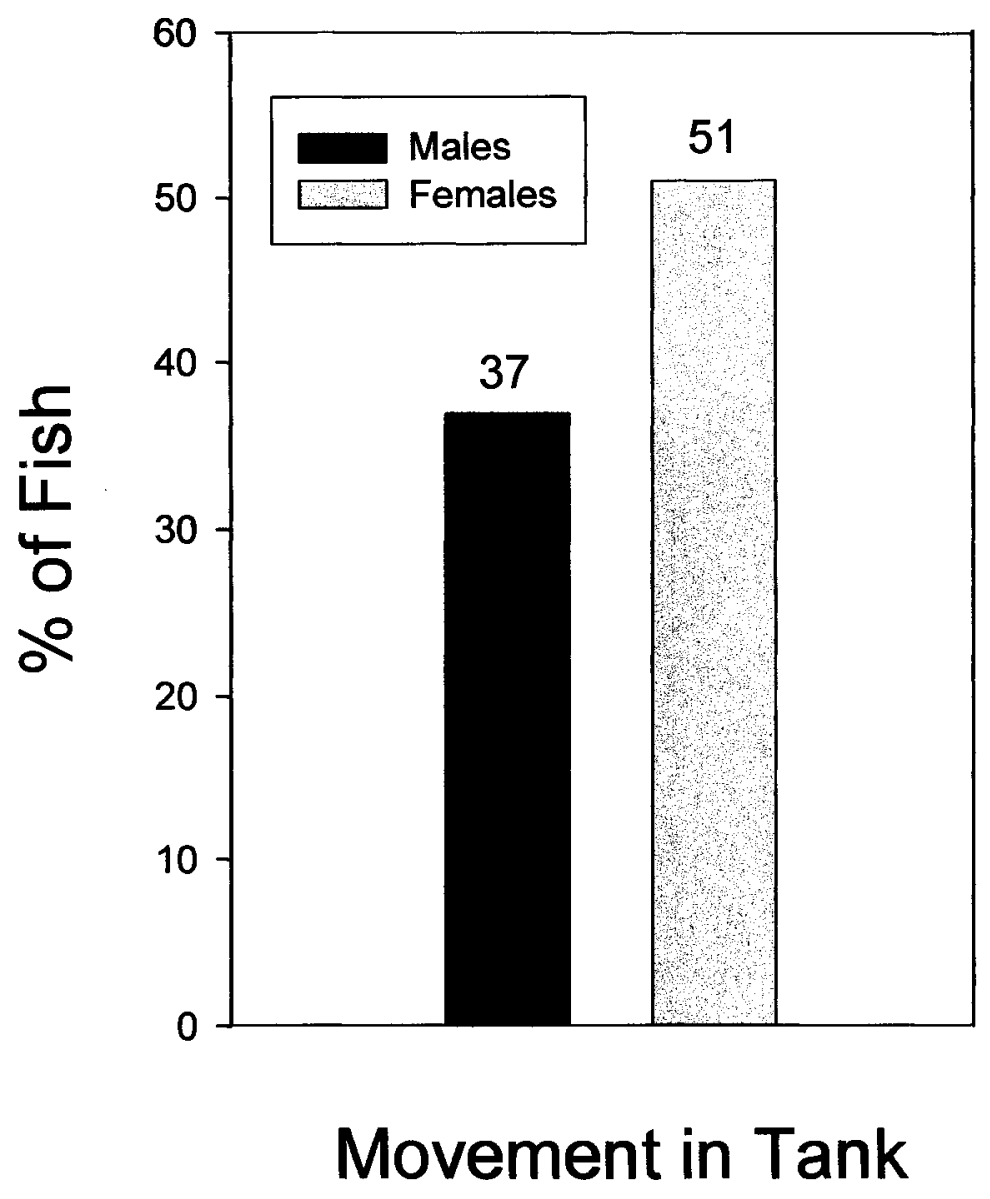

Figure 13: Movement of the round goby during experiment one in response to the male round goby spawning sound. Out of the 137 round gobies, 79 were male and 58 were female. Chi square showed no significant difference between sex and activity in the tank $(\mathrm{P}<$ $0.05)$. 


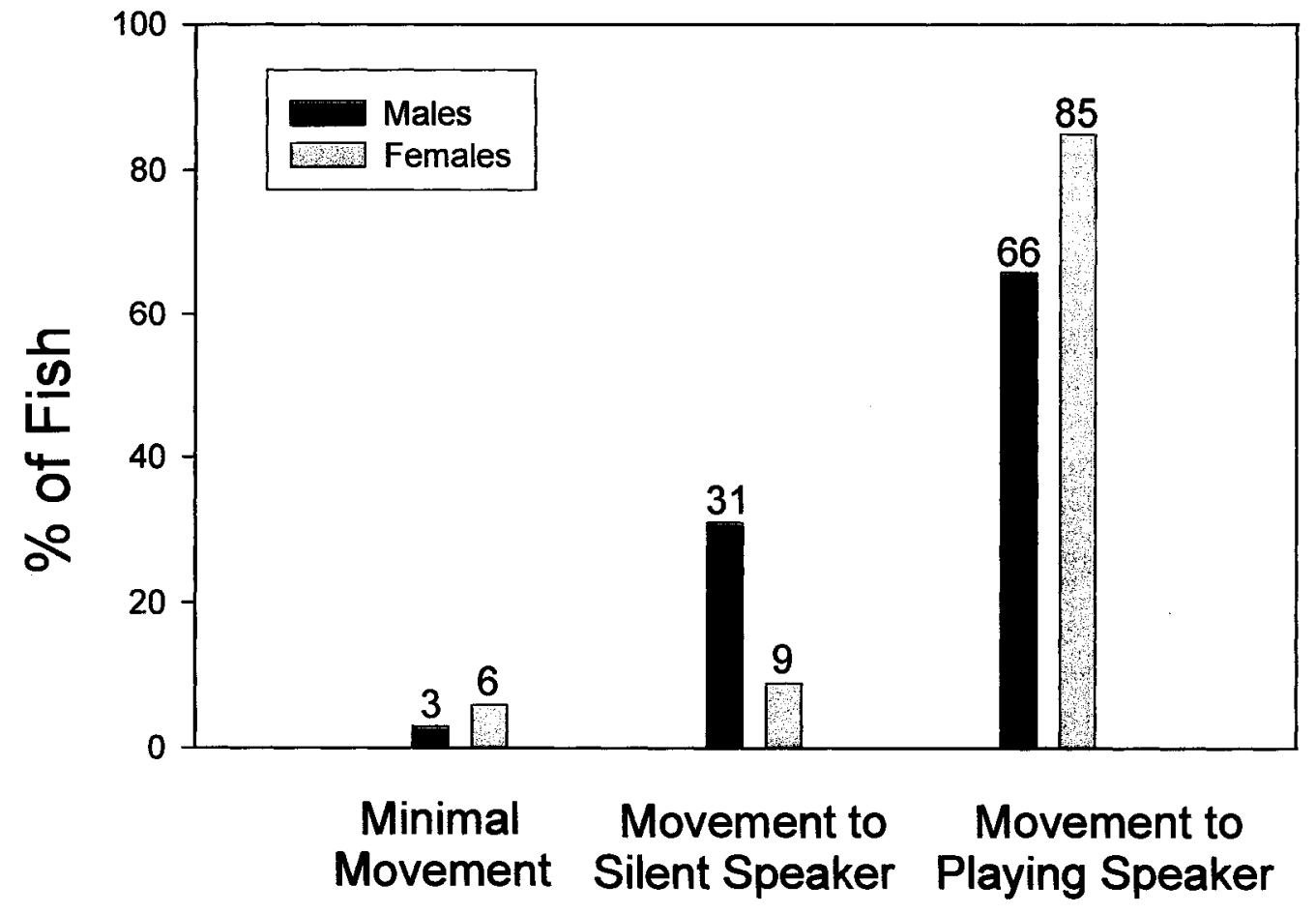

Figure 14: Responses of male and female round gobies in experiment one in response to male round goby spawning sounds. Movements include; less than $30 \mathrm{~cm}$ of movement into the tank (minimal movement), movement to the silent speaker, or movement to the speaker playing the sound. 


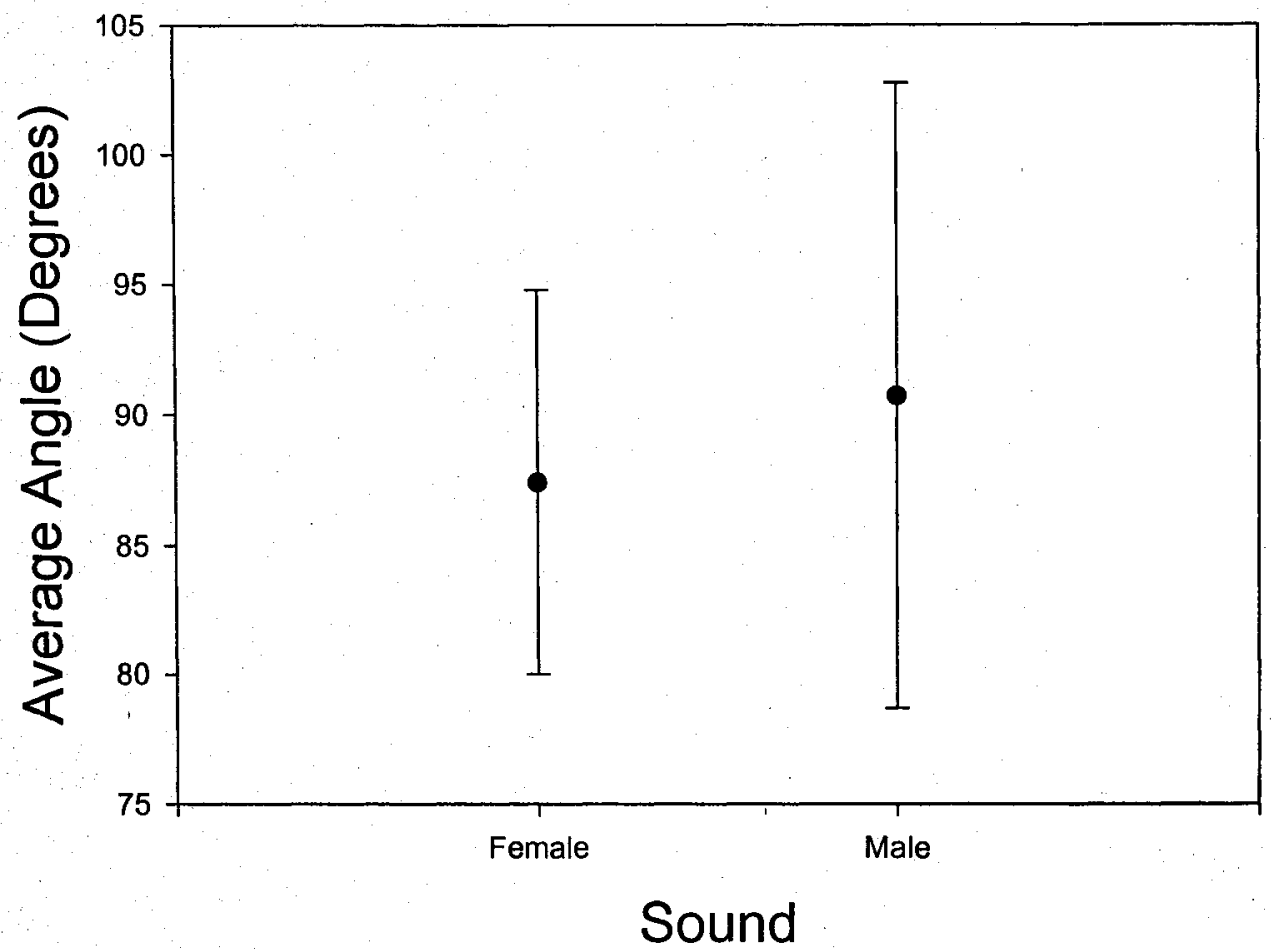

Figure 15: Average angle ( \pm 1 s.d.) of approach to the playing speaker of the round goby during experiment one. Out of the 137 round gobies, 79 were male and 58 were female. T-tests showed no significant difference between average angle and sex $(\mathrm{P}=$ $0.60, \mathrm{t}=0.91)$ 


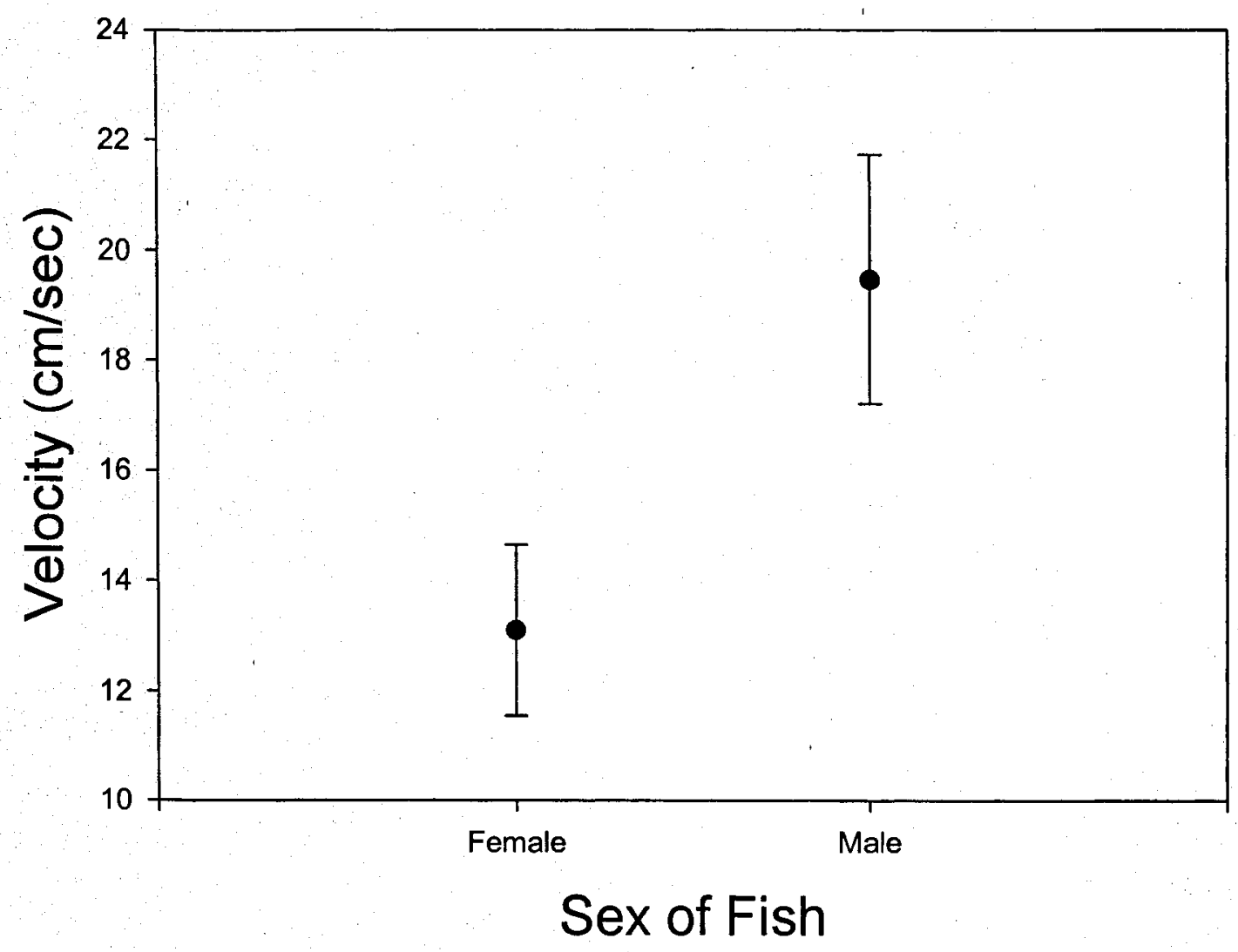

Figure 16: Swimming speed ( \pm 1 s.d.) of male and female round gobies in experiment one in response to male round goby spawning sounds. Out of the 137 round gobies, 79 were male and 58 were female. T-tests showed significant difference between sex and velocity $(P=0.04, t=2.20)$. 


\section{Experiment Two}

During the round goby call and the white noise trials, t-test found significant differences in size between sexes $(\mathrm{P}=.00$ for round goby call and $\mathrm{P}=.01$ for white noise). ,These significant differences indicate male gobies were larger than females for those trials. During the round goby call, $72 \%$ of the round gobies moved to the playing speaker, $6 \%$ moved to the silent speaker, and $6 \%$ moved to neither of the speakers (Figure 17). When the black goby call was played, $38 \%$ of the round gobies traveled to the playing speaker, $17 \%$ traveled to the silent speaker, and $33 \%$ moved to neither of the speakers. All of the round gobies moved to the playing speaker when the Italian goby call was played. During the playback of the $100 \mathrm{~Hz}$ tone burst, when the gobies moved during the experiment they either went to the playing speaker, $67 \%$, or to the silent speaker, $17 \%$. When white noise was played $56 \%$ of the gobies went to the playing speaker, $11 \%$ went to the silent speaker, and $6 \%$ moved in the tank (but to neither of the speakers).

When moving towards the playing speaker, all of the round gobies traveled within 10 $\mathrm{cm}$ of the speaker in response to the round goby call (Figure 18). During the black goby call, $15 \%$ moved within $13-18 \mathrm{~cm}$ from the playing speaker, and $23 \%$ came within $18-30 \mathrm{~cm}$. For the Italian goby call, $85 \%$ moved within $10 \mathrm{~cm}$ of the playing speaker, $38 \%$ traveled $10-13 \mathrm{~cm}$ away from the playing speaker, and $8 \%$ of the round gobies moved $13-18 \mathrm{~cm}$, another $8 \% 18-30 \mathrm{~cm}$ away. When the $100 \mathrm{~Hz}$ tone was played, $62 \%$ of the gobies moved within $10 \mathrm{~cm}$ of the playing speaker, while $15 \%$ moved $10-13 \mathrm{~cm}$, with an additional $15 \% 13-18 \mathrm{~cm}$ away. During the white noise 


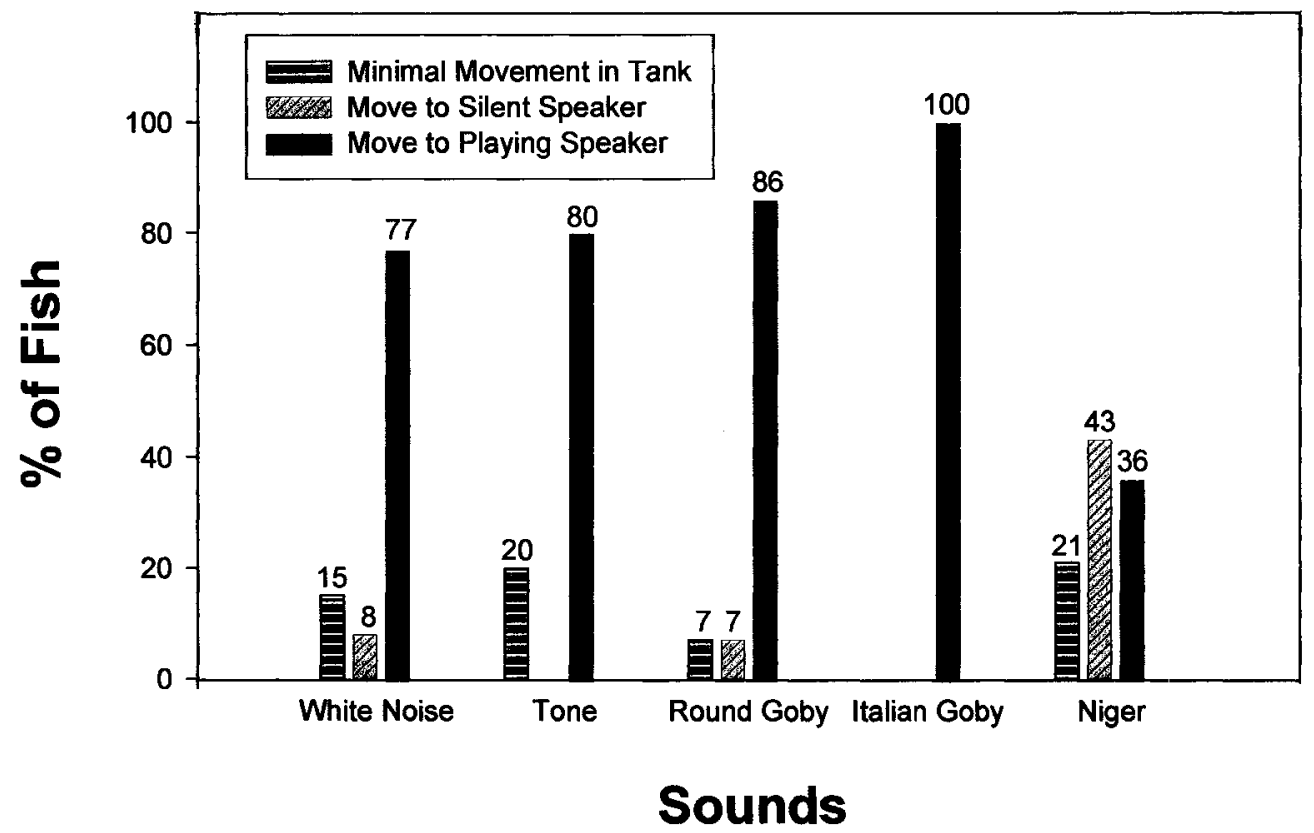

Figure 17: Behavioural responses of round gobies movement in response to male spawning sounds from the round goby $(n=15)$, black goby $(N i g e r)(n=$ 14), Italian goby $(\mathrm{n}=18), 100 \mathrm{~Hz}$ tone bursts (tone) $(\mathrm{n}=15)$, and white noise $(\mathrm{n}=14)$. Movements include; less than $30 \mathrm{~cm}$ of movement into the tank (minimal movement), movement to the silent speaker, or movement to the speaker playing the sound. 


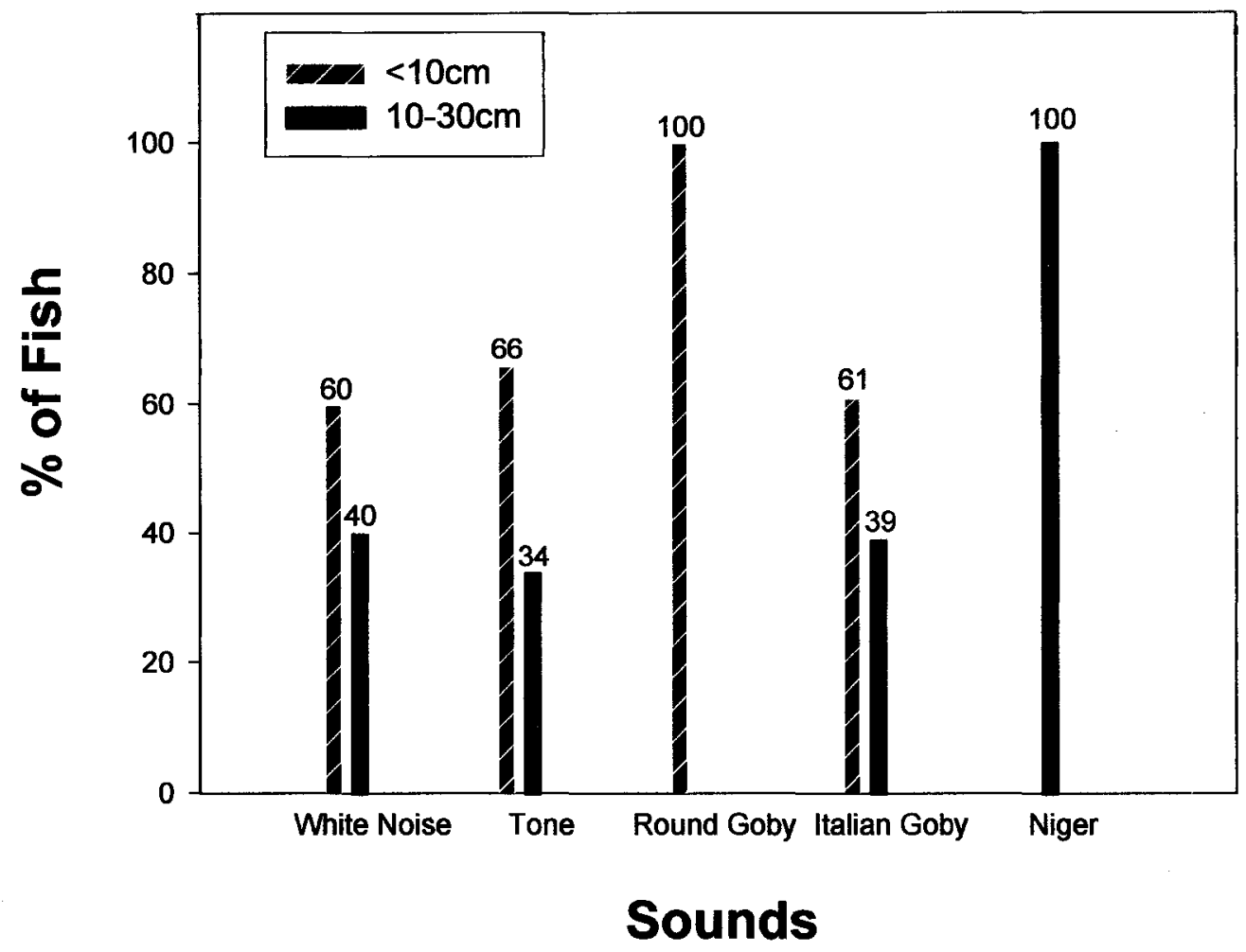

Figure 18: Proximity to the playing speaker of the round goby at cessation of movement during experiment two for spawning sounds from: round goby (n $=13)$, black goby $(\mathrm{Niger})(\mathrm{n}=5)$, Italian goby $(\mathrm{n}=18), 100 \mathrm{~Hz}$ tone bursts (tone) $(\mathrm{n}=12)$, and white noise $(\mathrm{n}=10)$. Category groupings according to distance traveled by goby to the speaker playing the sound stimulus; within $10 \mathrm{~cm}$ of the speaker or goby movement up to $10-30 \mathrm{~cm}$ away from the playing speaker. 
experiment, $46 \%$ of the fish moved within $10 \mathrm{~cm}$ of the playing speaker, $15 \%$ come within $10-13 \mathrm{~cm}, 8 \% 13-18 \mathrm{~cm}$, and another $8 \% 18-30 \mathrm{~cm}$ away from the playing speaker. Refer to Appendix C for individual activity.

The average speed of the round goby, from the net to the speaker playing the sound, was $10.8 \mathrm{~cm} / \mathrm{sec}$ for (B), $11.5 \mathrm{~cm} / \mathrm{sec}$ for (I), $20.8 \mathrm{~cm} / \mathrm{sec}$ for (R), $13.3 \mathrm{~cm} / \mathrm{sec}$ for (T), $14.7 \mathrm{~cm} / \mathrm{sec}$ for (W), and $9.9 \mathrm{~cm} / \mathrm{sec}$ for (S) (Figure 19). There was a significant difference in average velocity between males and females; males would travel at a faster speed to the playing speaker than females $(\mathrm{P}=.03)$. The standard error for average velocity data was $1.6 \mathrm{~cm} / \mathrm{sec}$ for (B), $1.1 \mathrm{~cm} / \mathrm{sec}(\mathrm{I}), 2.6 \mathrm{~cm} / \mathrm{sec}(\mathrm{R}), 1.4$ $\mathrm{cm} / \mathrm{sec}(\mathrm{T}), 1.9 \mathrm{~cm} / \mathrm{sec}(\mathrm{W})$, and $2.0 \mathrm{~cm} / \mathrm{sec}(\mathrm{S})$. No significant differences in velocity between sexes. Refer to Appendix D for individual velocity. The standard deviation for velocity data was $2.23^{\circ}$ for $(B), 2.19^{\circ}(\mathrm{I}), 7.78^{\circ}(\mathrm{R}), 3.95^{\circ}(\mathrm{T}), 1.98^{\circ}(\mathrm{W})$, and $5.96^{\circ}$ (S) (Figure 20). Velocity standard deviation had no significant difference for sound $(\mathrm{P}=.36)$ and sex $(\mathrm{P}=.18)$. Refer to Appendix $\mathrm{D}$ for individual standard deviations in velocity. The average angle from start point of the round goby to the speaker playing the sound was $113.2^{0}$ for (B), $97.2^{0}$ for (I), $90.8^{0}$ for (R), $107.8^{0}$ for (T), $102.6^{\circ}$ for (W), and $104.2^{0}$ for (S) (Figure 21). No significant difference was found between average angle and sound $(\mathrm{P}=.66)$ and sex $(\mathrm{P}=.15)$. Refer to Appendix $\mathrm{F}$ for individual average angles. There was a significant difference $(\mathrm{P}=$ 0.01 ) in the standard deviation of mean angle (Figure 22), with the smallest angle deviation found in response to round goby calls. Thus fish made the most direct path to the speaker when the round goby call was being played. There was no affect of sex 


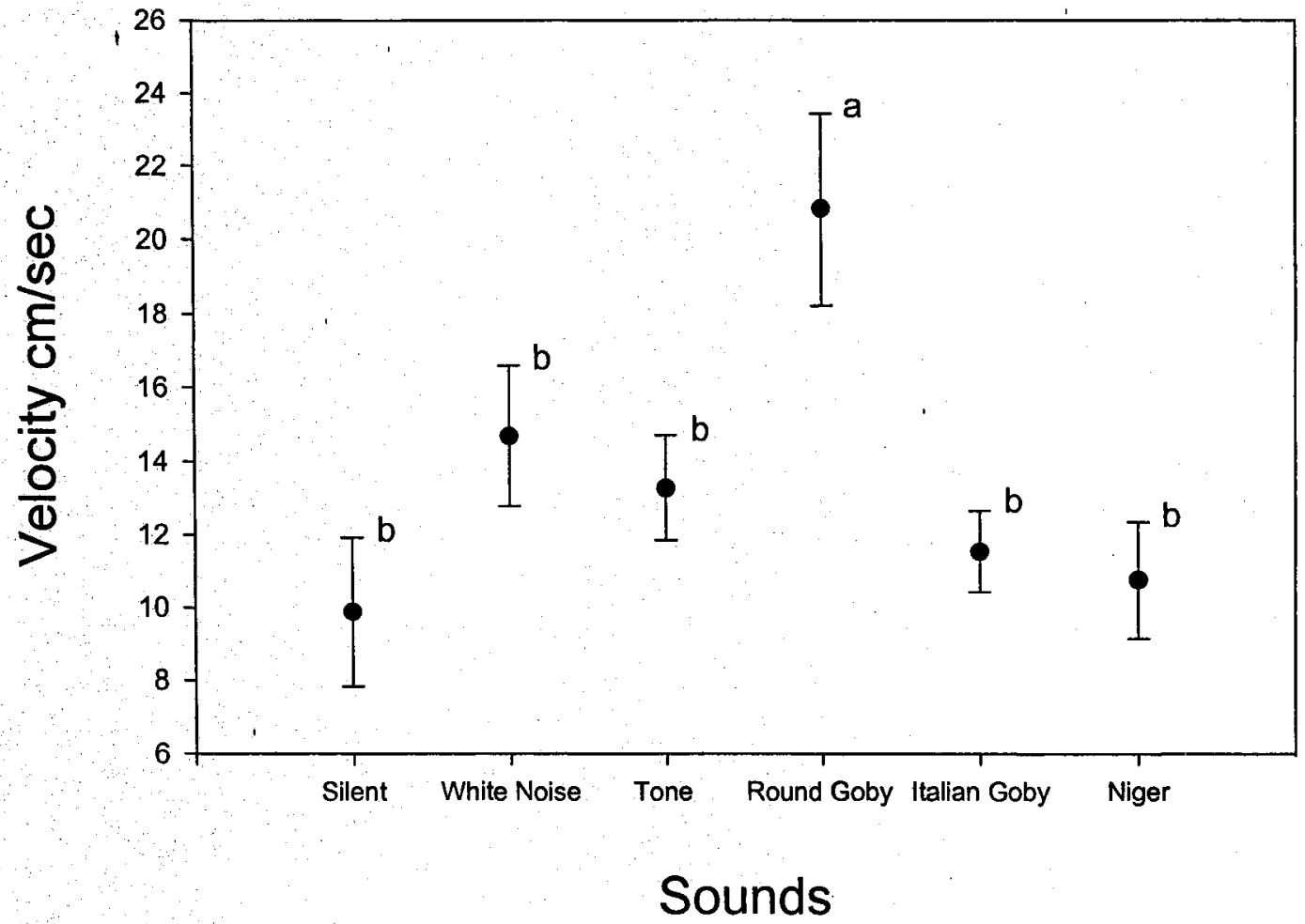

Figure 19: Average swimming speed ( \pm s.e.) of round goby in experiment two in response to six different stimuli. Silent refers to the control in the experiment (a quiet tank). ANOVA tests showed significant difference between sound and the velocity of the fish to the speaker playing the male round goby spawning sound $(\mathrm{P}=.03, \mathrm{~F}=2.69)$. Data points with different superscripts denote significant differences found in Tukey posthoc test. 


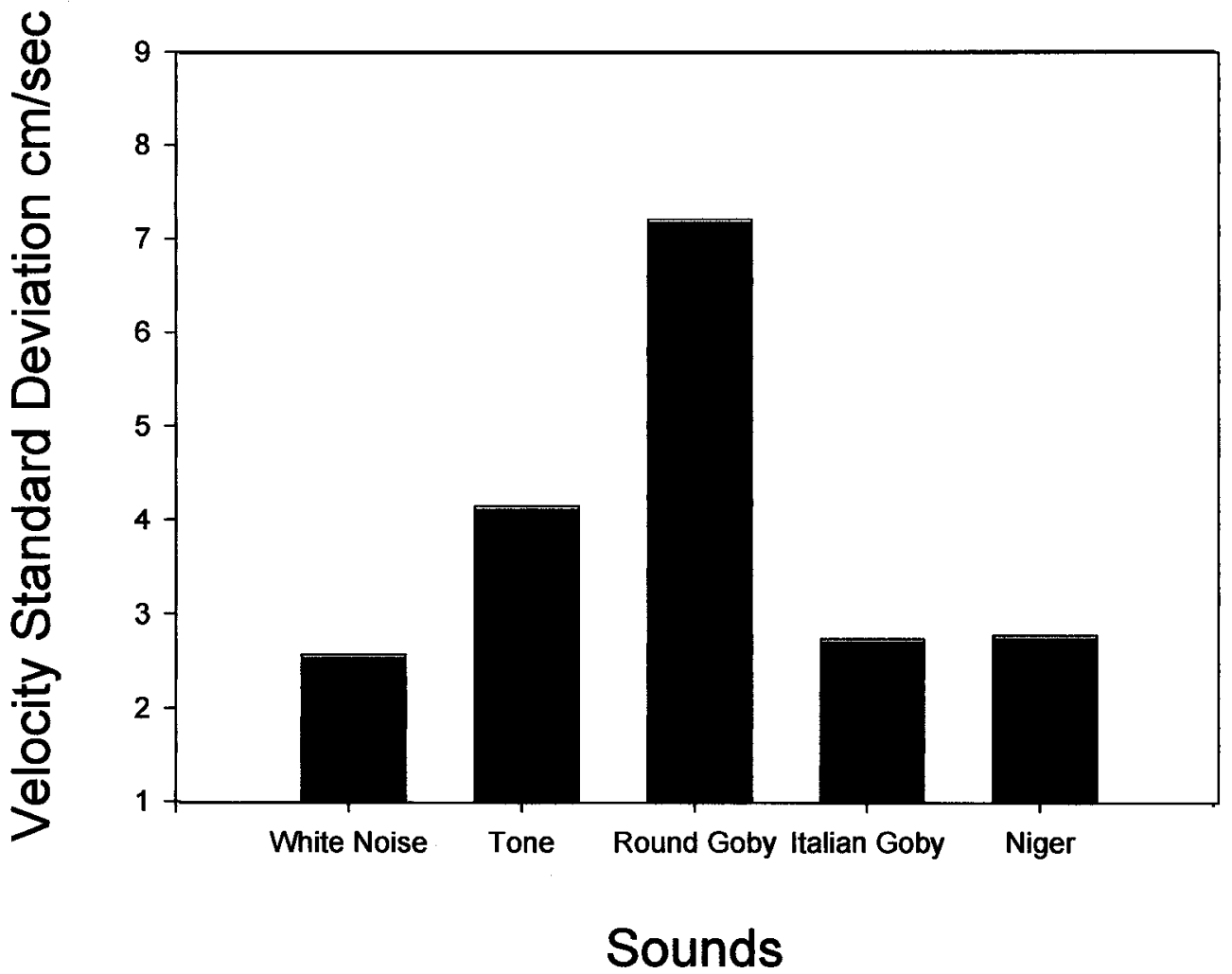

Figure 20: The standard deviation in swimming speed of round goby during movement to the playing speaker (experiment two). ANOVA test showed velocity standard deviation had no significant difference for sound $(\mathrm{P}=0.36$; $\mathrm{F}=1.12)$ or $\operatorname{sex}(\mathrm{P}=0.18 ; \mathrm{F}=1.85)$. 


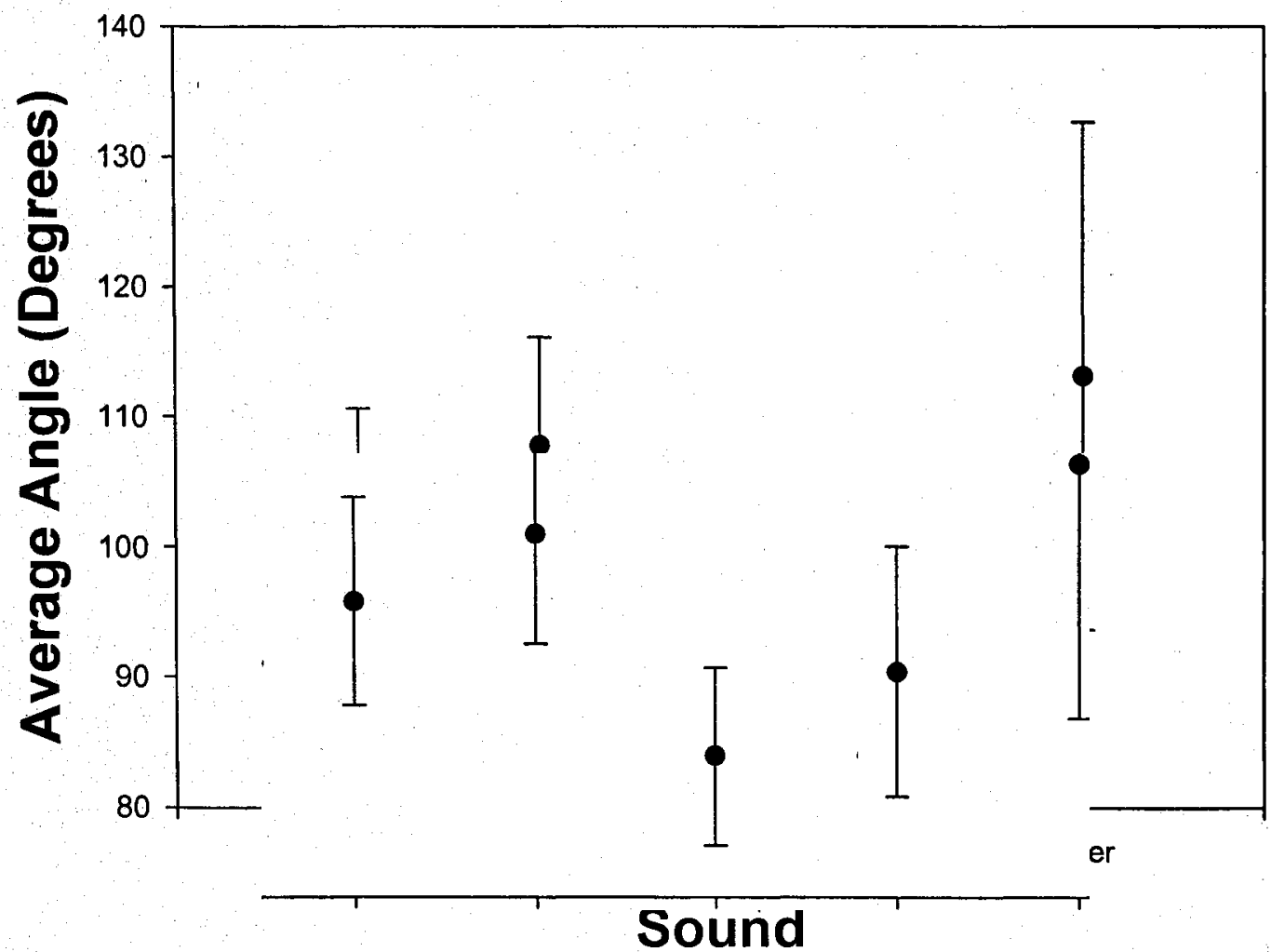

Figure 21: The average angle ( \pm s.e.) of approach to the playing speaker of round gobies in experiment two. ANOVA test showed no significant difference between average angle and sound $(P=0.66 ; F=$ $0.27)$ and $\operatorname{sex}(P=0.15 ; F=1.70)$. 


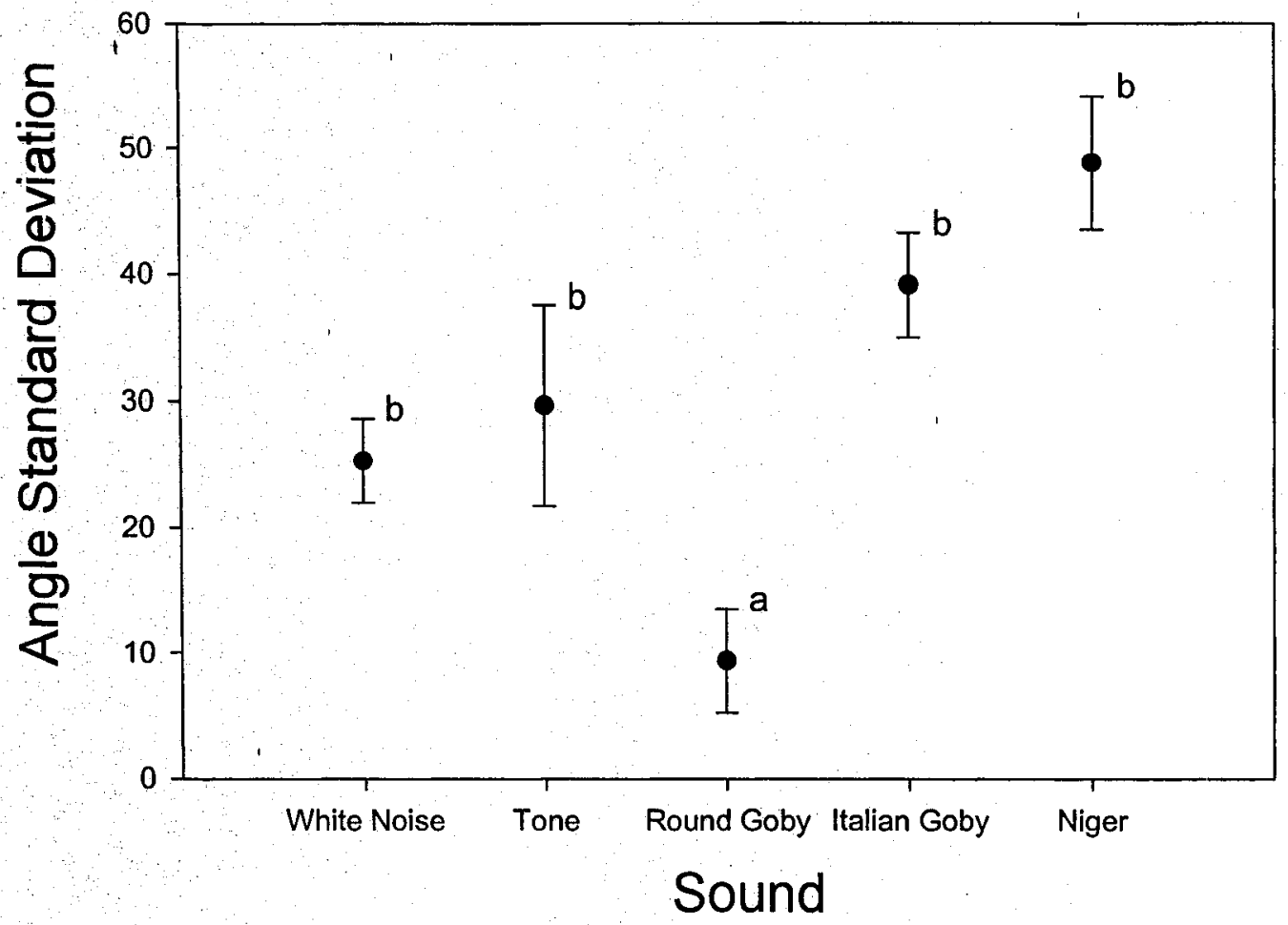

Figure 22: The standard deviation in approach angle of round gobies during movement to the playing speaker (experiment two). ANOVA test showed a significant difference between the male round goby spawning sound and angle standard deviation $(\mathrm{P}=0.01 ; \mathrm{F}=5.90)$. Data points with different superscripts denote significant differences found in Tukey posthoc test. 
on responses nor was there a significant sound and sex interaction. Refer to Appendix $\mathrm{G}$ for individual standard deviations in angles.

\section{Discussion}

The current study shows a clear behavioural attraction of both male and female round gobies to male sounds. The motivation for this response remains unclear however. Sound can indicate if the fish is suitable for reproduction, an attractant for the opposite sex, if the fish is primed to copulate, or if it can defend its spawning habitat. Females could travel towards the speaker playing the sound for reproductive intentions. Hawkins (2000) studied the haddock (Melanogrammus aeglefinus) and showed male fish produce a series of 'knocking' sounds during the spawning season. The male initially produces a short series of slowly repeated 'knocks' until the sounds becomes longer and faster (coinciding with an increase in arousal of the male). These sounds attract the female to the nest, synchronising the reproductive behaviour of the male and female. Female midshipman show directed movements in response to male reproductive calls (McKibben and Bass 1998) and Lugli et al. (1995) found that freshwater Italian gobies emit 'drumming' sounds to lure females into the nest. Thus the sounds in the current experiment could be enticing the female round goby to find a potential mate. Males might swim towards the playing speaker to investigate a potential competitor with the objective of vacating the reproductive male from the area. Stammler and Corkum (2005) showed larger round gobies displacing smaller gobies in their nest without a fight (purely based on size). This would stand to reason, since the gobies in this experiment (newly found in a foreign environment) 
might be more interested in investigating a potentially new home, with the chance of being the larger fish. Finally, some fish species employ competitive mating strategies in which extra-pair copulations is common (reviewed in Taborsky 2001). Male round gobies may be attracted to conspecific male sounds to employ a "sneaker male" strategy as seen in midshipman (e.g. Bass and McKibben 2003).

The current study also clearly shows that round gobies show specificity for conspecific sounds. In both experiments, the round goby consistently traveled to the playing speaker (more than any other movement in the tank), as well as traveled within the closest proximity to the playing speaker than during any other sound. Effect of intraspecific sound communication has been shown in other species as well, mainly during mating (sunfishes, Gerald, 1971; damselfishes, Myrberg et al., 1986; toadfishes, McKibben and Bass, 1998) and during agonistic interactions (Ladich, 1997). All of the sounds in this experiment varied, with differences in temporal structure, although the fundamental frequencies were similar. Since males show specificity for conspecific spawning sounds, future experiments could alter the spectral content of sound, by altering the number of pulses or adjusting the frequency to a higher or lower octave (or both, McKibben and Bass, 1998). This could determine which characteristic of the round goby call is of interest to them. Spawning sounds from other species comparable to the round goby spawning sound could also be used to determine if there is a similarity in behaviour response.

Significant findings were found in velocity, with males moving twice as fast to the playing speaker than females. Since males were significantly larger than the females, 
the difference in response velocity between sexes could be due to effects of size. Ware (1978) found that sockeye salmon (Oncorhynchus nerka) had swimming speeds proportional to their body length. In pink salmon (Oncorhynchus gorbuscha) both sex and reproductive status can affect swimming speed (Williams and Bell 1987). Males swim twice as fast as females during upstream movement and speed decreases as spawning progresses. In the round goby, the males were also twice as fast to swim towards the sound source. Since the experiment was conducted during the spawning season, and swimming speed might be influenced by reproductive behaviour, future experiments could look at the round gobies localization abilities outside of this season.

Sound plays an important role in spawning by indicating to fish the position of a possible mate or a potential competitor (Johnston and Johnson 2000). Determining the direction of that sound is essential in becoming the first to initiate spawning. The current study shows that not only is the round goby most attracted to conspecific spawning sounds, they are able to get to the sound source using a direct path and at faster speeds than any of the other sounds presented in this study. Although not conclusive, these findings suggest that the round goby shows a high specificity towards conspecific spawning cues. These findings are currently being used in our laboratory in an attempt to devise a selective trap for this invasive species.

When looking into the behavioural aspects of sound recognition, significant results occurred with standard deviation in angle, where the round goby had the most direct path to the round goby call than any other sound played. This minimal standard 
deviation in angle of approach to a sound source indicates the fish's ability to localize where in space the sound is originating rather than just sampling sounds in different locations in the tank. If a fish could not localize a sound source, its path would not be as direct, showing a zigzag pattern, deciphering where the sound is coming from. While moths are well known to be able to find odour cues from a distance, they do not show true directionality; instead they zigzag across the odour plum until honing in on the sources location (Willis and Baker 1994). Localization requires a straight line path from a distance to the source of interest, as is shown in the current study. This is one of the first studies to demonstrate this ability in fish in such a quantified manner.

The mechanism through which round gobies determine sound source location still remains obscure. Fish can detect sound directly through particle displacement of auditory hair cells, via reradiating sound from a swim bladder (when available), and/or via stimulation of the mechanosensory hair cells of the lateral line system (if the sound is of low enough frequency) (Popper and Platt 1993). Much of the theoretical work on directional hearing in fish has concerned differential phase analysis of species with swim bladders (e.g. Schuif 1975, Rogers and Cox, 1988). Round gobies have no swim bladder but can still clearly localize a sound source, therefore the mechanism of this localization must be found in the auditory and/or mechanosensory hair cells. In the current behavioural trials, fish started well within the near field of the fundamental frequency of the goby call (near field/far field boundary $=140 \mathrm{~cm}$ assuming a monopole source). Thus particle displacement should predominate in the sound field, making it likely that both the ear and neuromasts are involved in the behavioural response seen. Future experiments that selectively ablate 
the neuromasts (e.g. Baker and Montgomery, 1999) might be able to separate the roles of these two systems in goby localization but it seems clear that round gobies can indeed directly localize a sound source. 
Appendix A: Standard deviation and average angles of individual round gobies in experiment one.

\begin{tabular}{|c|c|c|c|c|c|c|c|}
\hline $\begin{array}{l}\text { Date } \\
(2004) \\
\end{array}$ & $\begin{array}{c}\text { Trial } \\
\#\end{array}$ & $\underline{\text { Sex }}$ & $\begin{array}{l}\text { Size } \\
(\mathrm{cm}) \\
\end{array}$ & Min Angle & Max Angle & $\frac{\text { Average }}{\text { Angle }}$ & $\begin{array}{c}\text { Angle std } \\
\text { dev }\end{array}$ \\
\hline 03-Aug & 4 & $F$ & $\overline{8.89}$ & 138.493 & 106.289 & $\overline{109.7}$ & $\overline{8.07}$ \\
\hline 07-Aug & 2 & $F$ & 8.89 & 93.012 & 72.718 & 87.4 & 3.978 \\
\hline 07-Aug & 4 & $F$ & 6.35 & 77.002 & 35.041 & 58.4 & 10.693 \\
\hline 09-Aug & 1 & $F$ & 11.43 & 123.142 & 46.228 & 93 & 15.479 \\
\hline 09-Augg & 2 & $F$ & 10.16 & 128.19 & 73.822 & 101.5 & 16.133 \\
\hline 09-Aug & 3 & $F$ & 8.89 & 109.615 & 62.823 & 92.1 & 11.724 \\
\hline 21-Aug & 4 & $F$ & 10.16 & 93.801 & 55.956 & 73 & 9.331 \\
\hline 25-Aug & 1 & $F$ & 10.16 & 94.566 & 63.595 & 88.3 & 7.327 \\
\hline 25-Aug & 2 & $F$ & 10.16 & 118.337 & 79.26 & 98.9 & 11.17 \\
\hline 26-Aug & 1 & $F$ & 7.62 & 93.21 & 56.449 & 76.9 & 11.421 \\
\hline 26-Aug & 2 & $F^{\prime}$ & 6.35 & 70.382 & 21.103 & 45.7 & 40.772 \\
\hline 30-Aug & 3 & $F$ & 7.62 & 156.706 & 63.224 & 109.1 & 26.379 \\
\hline 30-Aug & 5 & $F$ & 8.89 & 93.012 & 72.718 & 86.7 & 3.978 \\
\hline 31-Aug & 1 & $F$ & 8.89 & 99.306 & 73.247 & 85.3 & 6.167 \\
\hline 31-Aug & 4 & $F$ & 7.62 & 125.868 & 86.355 & 105 & 9.609 \\
\hline 03-Aug & 1 & $M$ & 10.16 & 124.445 & 82.72 & 95.1 & 11.521 \\
\hline 03-Aug & 2 & $M$ & 8.89 & 143.08 & 80.104 & 126 & 13.873 \\
\hline 03-Aug & 3 & $M$ & 7.62 & 84.647 & 31.91 & 59.6 & 11.965 \\
\hline 07-Aug & 1 & $M$ & 13.97 & 120.431 & 16.808 & 77.9 & 27.31 \\
\hline 07-Aug & 3 & $M$ & 5.08 & 92.473 & 36.249 & 68.4 & 14.037 \\
\hline 21-Aug & 1 & $M$ & 10.16 & 99.273 & 43.095 & 78.2 & 20.234 \\
\hline 21-Aug & 2 & $M$ & 12.7 & 127.826 & 86.427 & 101.1 & 9.119 \\
\hline 21-Aug & 3 & $M$ & 12.7 & 102.955 & 78.828 & 91.8 & 5.666 \\
\hline 30-Aug & 1 & $M$ & 12.7 & 173.731 & 100.804 & 116 & 14.884 \\
\hline 30-Aug & 2 & $M$ & 12.7 & 104.655 & 63.175 & 80.1 & 10.571 \\
\hline 30-Aug & 4 & $M$ & 10.16 & 128.806 & 75.557 & 96 & 11.501 \\
\hline 30-Aug & 6 & $M$ & 8.89 & 146.188 & 96.739 & 109.6 & 15.364 \\
\hline 30-Aug & 7 & $M$ & 12.7 & 90.311 & 59.565 & 77.4 & 7.958 \\
\hline 31-Aug & 2 & $M$ & 11.43 & 122.473 & 93.812 & 104.1. & 7.677 \\
\hline 31-Aug & 3 & $M$ & 12.7 & 124.07 & 85.004 & 102.6 & 8.665 \\
\hline 12-Sep & 1 & $M$ & 6.985 & 101.417 & 67.888 & 88.1 & 7.537 \\
\hline 12-Sep & 2 & $M$ & 12.7 & 142.343 & 65.284 & 98.5 & 14.862 \\
\hline 12-Sep & 3 & $M$ & 12.7 & 84.189 & 34.608 & 62.2 & 10.77 \\
\hline 12-Sep & 4 & $M$ & 12.7 & 152.083 & 50.224 & 90.6 & 29.086 \\
\hline \multicolumn{8}{|l|}{ Total } \\
\hline Avg $F$ & & & 8.805 & 107.64 & 64.589 & 87.4 & 7.379 \\
\hline Avg M & & & 10.929 & 119.23 & 65.726 & 90.7 & 12.035 \\
\hline
\end{tabular}


Appendix B: Standard deviation and average velocity of individual round gobies to the playing speaker in experiment one.

\begin{tabular}{|c|c|c|c|c|c|c|c|}
\hline $\begin{array}{c}\text { Date } \\
(2004)\end{array}$ & $\begin{array}{c}\text { Trial } \\
\#\end{array}$ & Sex & $\begin{array}{l}\text { Size } \\
(\mathrm{cm})\end{array}$ & $\begin{array}{c}\text { Min } \\
\text { Velocity }\end{array}$ & $\begin{array}{c}\text { Max } \\
\text { Velocity }\end{array}$ & $\begin{array}{l}\text { Average } \\
\text { Velocity }\end{array}$ & $\begin{array}{c}\text { Velocity std } \\
\text { dev }\end{array}$ \\
\hline 03-Aug & $\overline{4}$ & $\mathrm{~F}$ & 8.89 & 0.137 & $\overline{16.019}$ & 6.73 & $5 . \overline{538}$ \\
\hline 07-Aug & 2 & $F$ & 8.89 & 13.589 & 36.074 & 21.83 & 5.133 \\
\hline 07-Aug & 4 & $F$ & 6.35 & 0.059 & 23.208 & 8.469 & 7.674 \\
\hline 09-Aug & 1 & $F$ & 11.43 & 0.032 & 13.609 & 4.149 & 4.702 \\
\hline 09-Aug & 2 & $F$ & 10.16 & 6.117 & 20.85 & 14.48 & 3.031 \\
\hline 09-Aug & 3 & $F$ & 8.89 & 0.358 & 45.124 & 19.276 & 7.804 \\
\hline 21-Aug & 4 & $F$ & 10.16 & 3.625 & 28.231 & 16.071 & 5.601 \\
\hline 25-Aug & 1. & $F$ & 10.16 & 0.037 & 20.459 & 8.078 & 6.761 \\
\hline 25-Aug & 2 & $F$ & 10.16 & 6.236 & 32.864 & 18.048 & 6.778 \\
\hline 26-Aug & 1 & $F$ & 7.62 & 0.106 & 21.501 & 9.015 & 6.519 \\
\hline 26-Aug & 2 & $F$ & 6.35 & 0.024 & 16.905 & 4.629 & 5.181 \\
\hline 30-Aug & 3 & $F$ & 7.62 & 0.245 & 31.314 & 17.192 & 7.959 \\
\hline 30-Aug & 5 & $\mathbf{F}$ & 8.89 & 13.589 & 36.074 & 21.83 & 5.133 \\
\hline 31-Aug & 1 & $F$ & 8.89 & 0.074 & 18.455 & 12.048 & 4.052 \\
\hline 31-Aug & 4 & $\mathrm{~F}$ & 7.62 & 7.761 & 20.757 & 14.705 & 3.009 \\
\hline 03-Aug & 1 & $M$ & 10.16 & 0.067 & 31.057 & 10.955 & 9.905 \\
\hline 03-Aug & 2 & $M$ & 8.89 & 0.016 & 19.212 & 5.422 & 6.358 \\
\hline 03-Aug & 3 & $M$ & 7.62 & 0.085 & 16.357 & 8.392 & 6.029 \\
\hline 07-Aug & 1 & $M$ & 13.97 & 0.118 & 44.669 & 14.669 & 11.069 \\
\hline 07-Aug & 3 & $M$ & 5.08 & 0.1 & 14.625 & 5.611 & 4.725 \\
\hline 21-Aug & 1 & $M$ & 10.16 & 11.886 & 37.381 & 23.477 & 7.483 \\
\hline 21-Aug & 2 & $M$ & 12.7 & 13.654 & 34.433 & 21.639 & 4.237 \\
\hline 21-Aug & 3 & $M$ & 12.7 & 6.39 & 32.319 & 19.949 & 7.001 \\
\hline 30-Aug & 1 & $M$ & 12.7 & 9.801 & 152.075 & 46.733 & 32.186 \\
\hline 30-Aug & 2 & $M$ & 12.7 & 4.405 & 76.306 & 28.329 & 19.229 \\
\hline 30-Aug & 4 & $M$ & 10.16 & 12.964 & 28.455 & 19.649 & 3.942 \\
\hline 30-Aug & 6 & $M$ & 8.89 & 9.759 & 27.141 & 16.551 & 4.175 \\
\hline 30-Aug & 7 & $M$ & 12.7 & 9.783 & 77.324 & 33.531 & 13.838 \\
\hline 31-Aug & 2 & $M$ & 11.43 & 4.062 & 21.379 & 16.643 & 3.416 \\
\hline 31-Aug & 3 & $M$ & 12.7 & 9.065 & 26.574 & 17.879 & 4.211 \\
\hline 12-Sep & 1 & $M$ & 6.985 & 8.83 & 22.24 & 16.03 & 3.327 \\
\hline 12-Sep & 2 & $M$ & 12.7 & 11.694 & 39.788 & 24.218 & 7.942 \\
\hline 12-Sep & 3 & $M$ & 12.7 & 15.014 & 51.593 & 24.893 & 6.129 \\
\hline 12-Sep & 4 & $M$ & 12.7 & 0.06 & 28.404 & 15.44 & 8.806 \\
\hline \multicolumn{8}{|l|}{ Total } \\
\hline Avg $F$ & & & 8.805 & 3.466 & 25.43 & 13.10 & 5.658 \\
\hline Avg $M$ & & & 10.929 & 6.724 & 41.12 & 19.47 & 8.63 \\
\hline
\end{tabular}


Appendix C: Activity of individual round gobies during experiment two.

\begin{tabular}{|c|c|c|c|c|}
\hline Sound & Date & $\begin{array}{c}\text { Trial } \\
\#\end{array}$ & $\underline{\text { Sex }}$ & $\begin{array}{l}\text { Size } \\
\text { (cm) }\end{array}$ \\
\hline Black Goby & 27-Sep & 1 & $F$ & 8.89 \\
\hline Black Goby & 27-Sep & 4 & $F$ & 7.62 \\
\hline Black Goby & 27-Sep & 5 & $F$ & 7.62 \\
\hline Black Goby & 27-Sep & 6 & $F$ & 6.35 \\
\hline Black Goby. & 27-Sep & 8 & $F$ & 10.16 \\
\hline Black Goby & 27-Sep & 9 & $\mathrm{~F}$ & 7.62 \\
\hline Black Goby & 05-Oct & 4 & $F$ & 7.62 \\
\hline Black Goby & 27-Sep & 2 & $M$ & 7.62 \\
\hline Black Goby & 27-Sep & 3 & $M$ & 7.62 \\
\hline Black Goby & 27-Sep & 7 & $M$ & 7.62 \\
\hline Black Goby & 05-Oct & 1 & $M$ & 7.62 \\
\hline Black Goby & 05-Oct & 2 & $M$ & 8.89 \\
\hline Black Goby & $05-$ Oct & 3 & $M$ & 7.62 \\
\hline Black Goby & 05-Oct & 5 & $M$ & 11.43 \\
\hline Italian Goby & 15-Oct & 3 & $F$ & 7.62 \\
\hline Italian Goby & $15-$ Oct & 4 & $F$ & 7.62 \\
\hline Italian Goby & 15-Oct & 5 & $F$ & 7.62 \\
\hline Italian Goby & 15-Oct & 6 & $F$ & 10.16 \\
\hline Italian Goby & 15-Oct & 7 & $F$ & 8.86 \\
\hline Italian Goby & $15-$ Oct & 8 & $F$ & 10.16 \\
\hline Italian Goby & 23-Oct & 3 & $F$ & 7.62 \\
\hline Italian Goby & 23-Oct & 4 & $F$ & 7.62 \\
\hline Italian Goby & 23-Oct & 5 & $F$ & 7.62 \\
\hline Italian Goby & 23-Oct & 6 & $F$ & 7.62 \\
\hline Italian Goby & 23-Oct & 7 & $F$ & 10.16 \\
\hline Italian Goby & 23-Oct & 8 & $F$ & 8.89 \\
\hline Italian Goby & 15-Oct & 1 & $M$ & 7.62 \\
\hline Italian Goby & $15-$ Oct & 2 & $M$ & 7.62 \\
\hline Italian Goby & 15-Oct & 9 & $M$ & 10.16 \\
\hline Italian Goby & 23-Oct & 1 & $M$ & 8.89 \\
\hline Italian Goby & 23-Oct & 2 & $M$ & 7.62 \\
\hline Italian Goby & 23-Oct & 9 & $M$ & 7.62 \\
\hline Round Goby & 26-Aug & 1 & $F$ & 7.62 \\
\hline Round Goby & 26-Aug & 2 & $F$ & 6.35 \\
\hline Round Goby & 30-Aug & 3 & $F$ & 7.62 \\
\hline Round Goby & 30-Aug & 5 & $F$ & 8.89 \\
\hline Round Goby & 30-Aug & 1 & $M$ & 12.7 \\
\hline Round Goby & 30-Aug & 2 & $M$ & 12.7 \\
\hline Round Goby & 30-Aug & 4 & $M$ & 10.16 \\
\hline Round Goby & 30-Aug & 6 & $M$ & 8.89 \\
\hline Round Goby & 30-Aug & 7 & $M$ & 12.7 \\
\hline Round Goby & 31-Aug & 2 & $M$ & 11.43 \\
\hline Round Goby & 31-Aug & 3 & $M$ & 12.7 \\
\hline Round Goby & 12-Sep & 1 & $M$ & 6.985 \\
\hline Round Goby & 12-Sep & 2 & $M$ & 12.7 \\
\hline Round Goby & 12-Sep & 3 & M & 12.7 \\
\hline
\end{tabular}

Activity
Silent
Minimal Movement
Minimal Movement
Minimal Movement
Silent up to $27.94 \mathrm{~cm}$
Playing up to $27.94 \mathrm{~cm}$
Silent
Minimal Movement
Minimal Movement
Playing up to $20.32 \mathrm{~cm}$
Playing up to $15.24 \mathrm{~cm}$
Playing up to $20.32 \mathrm{~cm}$
Playing up to $15.24 \mathrm{~cm}$
Minimal Movement
Playing up to $10.16 \mathrm{~cm}$
Playing
Drive by Playing up to $12.7 \mathrm{~cm}$
Playing up to $22.86 \mathrm{~cm}$
Playing
Playing
Playing
Playing
Playing up to $15.24 \mathrm{~cm}$
Playing
Playing
Playing up to $12.7 \mathrm{~cm}$
Playing
Playing
Playing
Playing
Play Playing
Hid Playing
Playing
Playing
Playing
Playing
Playing
Playing
Playing
Playing
Drive by Playing up to $12.7 \mathrm{~cm}$
Playing to $12.7 \mathrm{~cm}$
Playing
Playing


Appendix C (continued): Activity of individual round gobies, experiment two.

\begin{tabular}{|c|c|c|c|c|c|}
\hline & & Trial & & Size & \\
\hline Sound & Date & \# & $\underline{\operatorname{Sex}}$ & $(\mathrm{cm})$ & Activity \\
\hline Round Goby & 12-Sep & 4 & M & 12.7 & Minimal Movement \\
\hline Silent & 05-Oct & 2 & $\mathrm{~F}$ & 7.62 & Jagged Movement \\
\hline Silent & 05-Oct & 3 & $\mathbf{F}$ & 7.62 & Jagged Movement \\
\hline Silent & 05-Oct & 5 & $\mathbf{F}$ & 10.16 & Jagged Movement \\
\hline Silent & 05-Oct & 6 & $\mathrm{~F}$ & 6.35 & Minimal Movement to Corner \\
\hline Silent & 18-Oct & 1 & $\mathrm{~F}$ & 7.62 & No Movement \\
\hline Silent & 05-Oct & 1 & $M$ & 7.62 & Minimal Movement to Corner \\
\hline Silent & 05-Oct & 4 & $M$ & 8.89 & Minimal Movement to Corner \\
\hline Silent & 05-Oct & 7 & M & 7.62 & Jagged Movement \\
\hline Tone & 20-Sep & 1 & $\mathrm{~F}$ & 8.89 & Playing \\
\hline Tone & 20-Sep & 2 & $\mathbf{F}$ & 10.16 & Playing \\
\hline Tone & 20-Sep & 3 & $\mathbf{F}$ & 10.16 & Playing \\
\hline Tone & 20-Sep & 6 & $\mathbf{F}$ & 7.62 & Drive by Playing up to $12.7 \mathrm{~cm}$ \\
\hline Tone & 20-Sep & 7 & $\mathbf{F}$ & 7.62 & Playing \\
\hline Tone & 20-Sep & 8 & $\mathrm{~F}$ & 7.62 & Playing \\
\hline Tone & 05-Oct & 2 & $\mathbf{F}$ & 7.62 & Silent to $10.16 \mathrm{~cm}$ \\
\hline Tone & 05-Oct & 4 & $F$ & 7.62 & Playing \\
\hline Tone & 05-Oct & 5 & $F$ & 8.89 & Silent \\
\hline Tone & 05-Oct & 6 & $\mathrm{~F}$ & 7.62 & Drive by Playing up to $15.24 \mathrm{~cm}$ \\
\hline Tone & 05-Oct & 7 & $\mathbf{F}$ & 7.62 & Hid Playing \\
\hline Tone & 20-Sep & 4 & $M$ & 7.62 & Playing \\
\hline Tone & 20-Sep & 5 & M & 7.62 & Playing up to $15.24 \mathrm{~cm}$ \\
\hline Tone & 05-Oct & 1 & $M$ & 7.62 & Drive by Playing up to $12.7 \mathrm{~cm}$ \\
\hline Tone & 05-Oct & 3 & $M$ & 10.16 & Silent \\
\hline White Noise & 04-Oct & 1 & $\mathbf{F}$ & 7.62 & Playing up to $25.4 \mathrm{~cm}$ \\
\hline White Noise & 04-Oct & 3 & $F$ & 7.62 & Playing up to $10.16 \mathrm{~cm}$ \\
\hline White Noise & 04-Oct & 4 & $\mathrm{~F}$ & 7.62 & Playing \\
\hline White Noise & $04-O c t$ & 7 & $\mathrm{~F}$ & 7.62 & Silent to $12.7 \mathrm{~cm}$ \\
\hline White Noise & 04-Oct & 8 & $F$ & 7.62 & Playing \\
\hline White Noise & 23-Oct & 1 & $\mathbf{F}$ & 7.62 & Playing up to $20.32 \mathrm{~cm}$ \\
\hline White Noise & 23-Oct & 2 & $\mathrm{~F}$ & 7.62 & Hid Playing \\
\hline White Noise & 23-Oct & 5 & $\mathrm{~F}$ & 6.35 & Playing \\
\hline White Noise & 04-Oct & 2 & $M$ & 7.62 & Silent \\
\hline White Noise & 04-Oct & 5 & M & 10.16 & Playing \\
\hline White Noise & 04-Oct & 6 & M & 8.89 & Drive by Playing up to $17.78 \mathrm{~cm}$ \\
\hline White Noise & 04-Oct & 9 & $M$ & 10.16 & Hid Playing \\
\hline White Noise & 23-Oct & 3 & M & 11.43 & Playing up to $12.7 \mathrm{~cm}$ \\
\hline White Noise & 23-Oct & 4 & $M$ & 7.62 & Minimal Movement \\
\hline
\end{tabular}


Appendix D: Standard deviation and average velocity of the round goby during experiment two.

\begin{tabular}{|c|c|c|c|c|c|c|c|c|}
\hline Sound & $\begin{array}{c}\text { Date } \\
(2004)\end{array}$ & $\begin{array}{c}\text { Trial } \\
\#\end{array}$ & $\underline{\text { Sex }}$ & $\begin{array}{l}\text { Size } \\
(\mathrm{cm})\end{array}$ & $\underline{\text { Min }}$ & $\underline{\text { Max }}$ & Average & std dev \\
\hline Black Goby & 27-Sep & $\overline{1}$ & $\bar{F}$ & 8.89 & 9.33 & 66.775 & 21.894 & 11.902 \\
\hline Black Goby & 27-Sep & 4 & $F$ & 7.62 & 0.123 & 19.576 & 5.66 & 4.508 \\
\hline Black Goby & 27-Sep & 5 & $\mathrm{~F}$ & 7.62 & 0.035 & 15.205 & 4.115 & 3.686 \\
\hline Black Goby & 27-Sep & 6 & $F$ & 6.35 & 10.897 & 24.573 & 18.592 & 3.763 \\
\hline Black Goby & 27-Sep & 8 & $F$ & 10.16 & 11.272 & 23.493 & 16.591 & 2.639 \\
\hline Black Goby & 27-Sep & 9 & $F$ & 7.62 & 0.076 & 21.483 & 9.208 & 5.384 \\
\hline Black Goby & 05-Oct & 4 & $\mathrm{~F}$ & 7.62 & 0.694 & 21.208 & 9.028 & 6.03 \\
\hline Black Goby & 27-Sep & 2 & $M$ & 7.62 & 0.299 & 14.413 & 5.416 & 3.941 \\
\hline Black Goby & 27-Sep & 3 & M & 7.62 & 0.097 & 17.734 & 6.05 & 4.671 \\
\hline Black Goby & 27-Sep & 7 & $M$ & 7.62 & 3.071 & 25.946 & 11.855 & 6.992 \\
\hline Black Goby & 05-Oct & 1 & M & 7.62 & 0.531 & 24.639 & 14.524 & 6.682 \\
\hline Black Goby & 05-Oct & 2 & M & 8.89 & 1.135 & 21.304 & 14.93 & 6.146 \\
\hline Black Goby & 05-Oct & 3 & M & 7.62 & 0.411 & 21.314 & 9.516 & 6.507 \\
\hline Black Goby & $05-$ Oct & 5 & M & 11.43 & 0.013 & 23.703 & 3.167 & 5.701 \\
\hline Italian Goby & 15-Oct & 3 & $F$ & 7.62 & 2.215 & 22.119 & 13.884 & 7.752 \\
\hline Italian Goby & $15-$ Oct & 4 & $F$ & 7.62 & 0.119 & 18.344 & 7.854 & 5.77 \\
\hline Italian Goby & $15-O c t$ & 5 & $F$ & 7.62 & 2.42 & 25.488 & 10.015 & 6.812 \\
\hline Italian Goby & 15-Oct & 6 & $F$ & 10.16 & 2.726 & 28.2 & 11.633 & 7.854 \\
\hline Italian Goby & $15-O c t$ & 7 & $F$ & 8.86 & 0.825 & 45.053 & 19.96 & 11.749 \\
\hline Italian Goby & $15-$ Oct & 8 & $\mathrm{~F}$ & 10.16 & 1.493 & 31.365 & 19.557 & 9.989 \\
\hline Italian Goby & 23-Oct & 3 & $F$ & 7.62 & 0.009 & 19.379 & 7.278 & 7.278 \\
\hline Italian Goby & 23-Oct & 4 & $F$ & 7.62 & 0.494 & 22.509 & 7.735 & 6.017 \\
\hline Italian Goby & $23-$ Oct & 5 & $F$ & 7.62 & 1.281 & 25.278 & 15.979 & 7.279 \\
\hline Italian Goby & 23-Oct & 6 & $F$ & 7.62 & 0.099 & 17.777 & 5.807 & 5.528 \\
\hline Italian Goby & $23-O c t$ & 7 & $F$ & 10.16 & 0.242 & 21.267 & 8.931 & 5.57 \\
\hline Italian Goby & $23-O c t$ & 8 & $\mathrm{~F}$ & 8.89 & 1.788 & 23.992 & 9.428 & 7.108 \\
\hline Italian Goby & $15-$ Oct & 1 & $M$ & 7.62 & 0.101 & 14.036 & 6.678 & 4.639 \\
\hline Italian Goby & $15-$ Oct & 2 & $M$ & 7.62 & 1.105 & 20.736 & 12.783 & 7.072 \\
\hline Italian Goby & $15-$ Oct & 9 & $M$ & 10.16 & 17.75 & 22.347 & 20.468 & 1.241 \\
\hline Italian Goby & $23-O c t$ & 1 & $M$ & 8.89 & 0.109 & 22.883 & 11.488 & 6.688 \\
\hline Italian Goby & 23-Oct & 2 & $M$ & 7.62 & 1.071 & 16.923 & 6.73 & 4.839 \\
\hline Italian Goby & 23-Oct & 9 & $M$ & 7.62 & 2.919 & 32.5 & 11.523 & 7.234 \\
\hline Round Goby & 26-Aug & 1 & $\mathrm{~F}$ & 7.62 & 0.106 & 21.501 & 9.015 & 6.519 \\
\hline Round Goby & 26-Aug & 2 & $F$ & 6.35 & 0.024 & 16.905 & 4.629 & 5.181 \\
\hline Round Goby & 30-Aug & 3 & $F$ & 7.62 & 0.245 & 31.314 & 17.192 & 7.959 \\
\hline Round Goby & 30-Aug & 5 & $F$ & 8.89 & 13.589 & 36.074 & 21.83 & 5.133 \\
\hline Round Goby & 30-Aug & 1 & $M$ & 12.7 & 9.801 & 152.075 & 46. & 32.186 \\
\hline Round Goby & 30-Aug & 2 & $M$ & 12.7 & 4.405 & 76.306 & & 19.229 \\
\hline Round Goby & 30-Aug & 4 & $M$ & 10.16 & 12.964 & 28.455 & 19.649 & 3.942 \\
\hline Round Goby & 30-Aug & 6 & $M$ & 8.89 & 9.759 & 27.141 & 16.551 & 4.175 \\
\hline Round Goby & 30-Aug & 7 & $M$ & 12.7 & 9.783 & 77.324 & 33.531 & 13.838 \\
\hline Round Goby & 31-Aug & 2 & $M$ & 11.43 & 4.062 & 21.379 & 16.643 & 3.416 \\
\hline Round Goby & 31-Aug & 3 & $M$ & 12.7 & 9.065 & 26.574 & 17.879 & 4.211 \\
\hline Round Goby & 12-Sep & 1 & $M$ & 6.985 & 8.83 & 22.24 & 16.03 & 3.327 \\
\hline Round Goby & 12-Sep & 2 & $M$ & 12.7 & 11.694 & 39.788 & 24.218 & 7.942 \\
\hline
\end{tabular}


Appendix D (continued): Standard deviation and average velocity of the round goby during experiment two.

\begin{tabular}{|c|c|c|c|c|c|c|c|c|}
\hline Sound & $\begin{array}{c}\text { Date } \\
(2004)\end{array}$ & $\begin{array}{c}\text { Trial } \\
\#\end{array}$ & $\underline{\text { Sex }}$ & $\begin{array}{l}\text { Size } \\
\text { (cm) }\end{array}$ & $\underline{\text { Min }}$ & Max & Average & std dev \\
\hline Round Goby & $\overline{12-S e p}$ & 3 & $M$ & $\overline{12.7}$ & 15.014 & $5 \overline{51.593}$ & 24.893 & 6.129 \\
\hline Round Goby & 12-Sep & 4 & $\mathrm{M}$ & 12.7 & 0.06 & 28.404 & 15.44 & 8.806 \\
\hline Silent & 05-Oct & 2 & $\mathrm{~F}$ & 7.62 & 0.085 & 23.639 & 8.893 & 6.928 \\
\hline Silent & 05-Oct & 3 & $F$ & 7.62 & 0.414 & 104.917 & 19.901 & 17.847 \\
\hline Silent & $05-O c t$ & 5 & $F$ & 10.16 & 0.337 & 22.003 & 12.966 & 6.161 \\
\hline Silent & 05-Oct & 6 & $F$ & 6.35 & 0.058 & 18.721 & 6.933 & 5.624 \\
\hline Silent & 18-Oct & 1 & $\mathrm{~F}$ & 7.62 & 0.059 & 0.129 & 0.097 & 0.021 \\
\hline Silent & 05-Oct & 1 & $M$ & 7.62 & 0.272 & 47.334 & 13.354 & 15.201 \\
\hline Silent & 05-Oct & 4 & $M$ & 8.89 & 0.011 & 45.665 & 9.831 & 12.666 \\
\hline Silent & $05-$ Oct & 7 & M & 7.62 & 0.017 & 21.674 & 7.136 & 5.163 \\
\hline Tone & 20-Sep & 1 & $F$ & 8.89 & 8.281 & 24.495 & 16.016 & 3.48 \\
\hline Tone & 20-Sep & 2 & $F$ & 10.16 & 6.328 & 26.408 & 17.583 & 4.168 \\
\hline Tone & 20-Sep & 3 & $\mathbf{F}$ & 10.16 & 13.65 & 28.915 & 20.773 & 3.665 \\
\hline Tone & 20-Sep & 6 & $F$ & 7.62 & 0.199 & 42.096 & 16.916 & 9.645 \\
\hline Tone & 20-Sep & 7 & $F$ & 7.62 & 0.367 & 22.753 & 12.198 & 4.981 \\
\hline Tone & 20-Sep & 8 & $F$ & 7.62 & 4.159 & 29.83 & 14.809 & 5.881 \\
\hline Tone & 05-Oct & 2 & $F$ & 7.62 & 0.192 & 23.376 & 7.826 & 6.407 \\
\hline Tone & 05-Oct & 4 & $F$ & 7.62 & 0.425 & 21.385 & 8.583 & 5.612 \\
\hline Tone & $05-$ Oct & 5 & $F$ & 8.89 & 0.507 & 62.015 & 18.083 & 15.972 \\
\hline Tone & $05-$ Oct & 6 & $F$ & 7.62 & 16.079 & 26.678 & 22.95 & 3.194 \\
\hline Tone & $05-$ Oct & 7 & $F$ & 7.62 & 0.815 & 17.471 & 7.014 & 5.122 \\
\hline Tone & 20-Sep & 4 & $M$ & 7.62 & 0.077 & 21.814 & 6.902 & 5.446 \\
\hline Tone & 20-Sep & 5 & $M$ & 7.62 & 0.056 & 15.72 & 4.432 & 4.264 \\
\hline Tone & $05-O c t$ & 1 & $M$ & 7.62 & 0.745 & 45.433 & 12.91 & 14.357 \\
\hline Tone & $05-$ Oct & 3 & M & 10.16 & 0.297 & 43.961 & 12.312 & 10.19 \\
\hline White Noise & 04-Oct & 1 & $F$ & 7.62 & 0.492 & 21.595 & 11.879 & 7.102 \\
\hline White Noise & 04-Oct & 3 & $F$ & 7.62 & 9.789 & 30.574 & 21.901 & 5.429 \\
\hline White Noise & 04-Oct & 4 & $F$ & 7.62 & 17.343 & 36.066 & 25.454 & 4.865 \\
\hline White Noise & 04-Oct & 7 & $F$ & 7.62 & 14.164 & 25.791 & 19.899 & 2.759 \\
\hline White Noise & 04-Oct & 8 & $F$ & 7.62 & 0.067 & 20.097 & 12.497 & 6.806 \\
\hline White Noise & 23-Oct & 1 & $F$ & 7.62 & 0.092 & 19.887 & 2.655 & 3.837 \\
\hline White Noise & 23-Oct & 2 & $F$ & 7.62 & 0.059 & 20.879 & 5.233 & 5.295 \\
\hline White Noise & 23-Oct & 5 & $F$ & 6.35 & 0.023 & 19.75 & 4.462 & 4.715 \\
\hline White Noise & 04-Oct & 2 & $M$ & 7.62 & 10.315 & 23.758 & 17.039 & 3.5 \\
\hline White Noise & $04-$ Oct & 5 & $M$ & 10.16 & 14.165 & 27.909 & 19.763 & 3.924 \\
\hline White Noise & 04-Oct & 6 & $M$ & 8.89 & 16.331 & 26.233 & 19.814 & 2.897 \\
\hline White Noise & 04-Oct & 9 & M & 10.16 & 11.257 & 36.034 & 22.985 & 8.083 \\
\hline White Noise & 23-Oct & 3 & M & 11.43 & 0.103 & 28.959 & 9.612 & 7.773 \\
\hline White Noise & 23-Oct & 4 & M & 7.62 & 0.168 & 37.096 & 12.411 & 8.718 \\
\hline
\end{tabular}


Appendix E: Standard deviation and average angle of the round goby during experiment two.

\begin{tabular}{|c|c|c|c|c|c|c|c|c|}
\hline Sound & $\begin{array}{c}\text { Date } \\
(2004)\end{array}$ & $\begin{array}{c}\text { Trial } \\
\#\end{array}$ & Sex & $\begin{array}{l}\text { Size } \\
(\mathrm{cm})\end{array}$ & $\underline{\text { Min }}$ & $\underline{\text { Max }}$ & Average & $\underline{\text { std dev }}$ \\
\hline Black Goby & $27-\mathrm{Sep}$ & $\overline{1}$ & $\bar{F}$ & 8.89 & $9 \overline{91.462}$ & $3 \overline{8.112}$ & 44.6 & 13.974 \\
\hline Black Goby & 27-Sep & 4 & $F$ & 7.62 & 52.959 & 48.829 & 2.76 & 29.096 \\
\hline Black Goby & 27-Sep & 5 & $\mathbf{F}$ & 7.62 & 72.935 & 42.766 & 2.21 & 31.177 \\
\hline Black Goby & 27-Sep & 6 & $\mathbf{F}$ & 6.35 & 156.119 & 54.976 & 97.5 & 31.819 \\
\hline Black Goby & 27-Sep & 8 & $F$ & 10.16 & 154.9 & 34.796 & 116.5 & 27.394 \\
\hline Black Goby & 27-Sep & 9 & $F$ & 7.62 & 283.765 & 109.006 & 205 & 60.815 \\
\hline Black Goby & $05-$ Oct & 4 & $F$ & 7.62 & 270.692 & 34.194 & 119.2 & 68.782 \\
\hline Black Goby & 27-Sep & 2 & $M$ & 7.62 & 273.305 & 101.807 & & 53.679 \\
\hline Black Goby & 27-Sep & 3 & $M$ & 7.62 & 344.255 & 83.895 & 202.5 & 75.794 \\
\hline Black Goby & 27-Sep & 7 & $M$ & 7.62 & 317.417 & 81.539 & 1.9 & 73.798 \\
\hline Black Goby & 05-Oct & 1 & $M$ & 7.62 & 273.911 & 60.12 & & 137 \\
\hline Black Goby & $05-O c t$ & 2 & $M$ & 8.89 & 217.867 & 29.057 & 3.1 & 7.328 \\
\hline Black Goby & 05-Oct & 3 & M & 7.62 & 259.366 & 39.168 & 129.8 & 56.192 \\
\hline Black Goby & 05-Oct & 5 & M & 11.43 & 53.597 & 89.296 & 34.6 & 47.066 \\
\hline Italian Goby & 15-Oct & 3 & $\mathrm{~F}$ & 7.62 & 182.385 & 77.288 & 120.6 & 34.983 \\
\hline Italian Goby & $15-$ Oct & 4 & $F$ & 7.62 & 119.827 & 80.253 & 45.4 & 60.441 \\
\hline Italian Goby & $15-$ Oct & 5 & $\mathrm{~F}$ & 7.62 & 142.994 & 8.946 & 5.9 & 33.02 \\
\hline Italian Goby & 15-Oct & 6 & $F$ & 10.16 & 91.199 & 67.112 & & 44.736 \\
\hline Italian Goby & $15-$ Oct & 7 & $F$ & 8.86 & 80.957 & 48.555 & .4 & 39.056 \\
\hline Italian Goby & $15-$ Oct & 8 & $F$ & 10.16 & 211.41 & 81.099 & 135.3 & 27.517 \\
\hline Goby & 23-Oct & 3 & $F$ & 7.62 & 145.018 & 41.252 & & 87 \\
\hline Italian Goby & 23-Oct & 4 & $F$ & 7.62 & 160.209 & 14.623 & 9.5 & 38.615 \\
\hline Italian Goby & 23-Oct & 5 & $F$ & 7.62 & 183.597 & 79.259 & 135.8 & 37.025 \\
\hline Italian Goby & 23-Oct & 6 & $F$ & 7.62 & 142.121 & 41.113 & & 26.551 \\
\hline Italian Goby & $23-$ Oct & 7 & $\mathbf{F}$ & 10.16 & 403.015 & 34.291 & 2.7 & 97.58 \\
\hline Italian Goby & 23-Oct & 8 & $F$ & 8.89 & 214.801 & 79.449 & 108 & 7.05 \\
\hline Italian Goby & 15-Oct & 1 & M & 7.62 & 157.298 & 30.848 & & .362 \\
\hline Italian Goby & $15-$ Oct & 2 & M & 7.62 & 135.281 & 19.465 & & 34.451 \\
\hline Italian Goby & 15-Oct & 9 & $M$ & 10.16 & 183.375 & 73.33 & 126.7 & 31.613 \\
\hline Italian Goby & 23-Oct & 1 & M & 8.89 & 178.509 & 12.741 & & 827 \\
\hline Goby & 23-Oct & 2 & M & 7.62 & 189.31 & 78.557 & 143.4 & 28.831 \\
\hline Italian Goby & 23-Oct & 9 & $M$ & 7.62 & 176.758 & 80.091 & 122.6 & 30.321 \\
\hline Round Goby & 26-Aug & 1 & $\mathrm{~F}$ & 7.62 & 93.21 & 56.449 & 69.9 & 11.421 \\
\hline ound Goby & 26-Aug & 2 & $F$ & 6.35 & 70.382 & 21.103 & & -40.772 \\
\hline Round Goby & 30-Aug & 3 & $F$ & 7.62 & 156.706 & 63.224 & 112.1 & 26.379 \\
\hline Round Goby & 30-Aug & 5 & $F$ & 8.89 & 93.012 & 72.718 & 77.7 & 3.978 \\
\hline Round Goby & 30-Aug & 1 & $M$ & 12.7 & 173.731 & 100.804 & 126 & 14.884 \\
\hline Round Goby & 30-Aug & 2 & $M$ & 12.7 & 104.655 & 63.175 & 84 & 10.571 \\
\hline Round Goby & 30-Aug & 4 & $M$ & 10.16 & 128.806 & 75.557 & 10 & 11.501 \\
\hline Round Goby & 30-Aug & 6 & $M$ & 8.89 & 146.188 & 96.739 & 117.6 & 15.364 \\
\hline Round Goby & 30-Aug & 7 & $M$ & 12.7 & 90.311 & 59.565 & 71.4 & 7.958 \\
\hline Round Goby & 31-Aug & 2 & $M$ & 11.43 & 122.473 & 93.812 & 114.1 & 7.677 \\
\hline Round Goby & 31-Aug & 3 & $M$ & 12.7 & 124.07 & 85.004 & 112.6 & 8.665 \\
\hline Round Goby & 12-Sep & 1 & $M$ & 6.985 & 101.417 & 67.888 & 83.1 & 7.537 \\
\hline Round Goby & 12-Sep & 2 & $M$ & 12.7 & 142.343 & 65.284 & 107.5 & 14.862 \\
\hline
\end{tabular}


Appendix E (continued): Standard deviation and average angle of the round goby during experiment two.

\begin{tabular}{|c|c|c|c|c|c|c|c|c|}
\hline Sound & $\begin{array}{c}\text { Date } \\
(2004) \\
\end{array}$ & $\begin{array}{c}\text { Trial } \\
\#\end{array}$ & $\underline{\text { Sex }}$ & $\begin{array}{l}\text { Size } \\
(\mathrm{cm})\end{array}$ & $\underline{\text { Min }}$ & $\underline{\text { Max }}$ & Average & $\underline{\text { std dev }}$ \\
\hline Round Goby & $\overline{12-S e p}$ & 3 & $\bar{M}$ & $\overline{12.7}$ & 84.189 & $3 \overline{4.608}$ & 49.2 & 10.77 \\
\hline Round Goby & 12-Sep & 4 & M & 12.7 & 152.083 & 50.224 & 98.6 & 29.086 \\
\hline Silent & $05-O c t$ & 2 & $F$ & 7.62 & 158.588 & 181.325 & 2.8 & 123.511 \\
\hline Silent & 05-Oct & 3 & $F$ & 7.62 & 330.049 & 46.574 & 156.2 & 57.558 \\
\hline Silent & 05-Oct & 5 & $F$ & 10.16 & 272.179 & 2.577 & 123.5 & 72.626 \\
\hline Silent & 05-Oct & 6 & $F$ & 6.35 & 184.685 & 96.454 & 148.3 & 24.675 \\
\hline Silent & 18-Oct & 1 & $F$ & 7.62 & 121.953 & 93.692 & 108.1 & 8.155 \\
\hline Silent & $05-$ Oct & 1 & M & 7.62 & 93.782 & 4.083 & 45.3 & 32.75 \\
\hline Silent & 05-Oct & 4 & M & 8.89 & 142.008 & 102.546 & 129.2 & 9.664 \\
\hline Silent & 05-Oct & 7 & M & 7.62 & 167.022 & 46.293 & 101.1 & 35.66 \\
\hline Tone & 20-Sep & 1 & $F$ & 8.89 & 115.048 & 84.571 & 99.6 & 8.002 \\
\hline Tone & 20-Sep & 2 & $F$ & 10.16 & 130.51 & 93.155 & 113.2 & 7.561 \\
\hline Tone & 20-Sep & 3 & $F$ & 10.16 & 123.098 & 90.458 & 107.6 & 8.438 \\
\hline Tone & 20-Sep & 6 & $\mathrm{~F}$ & 7.62 & 150.651 & 51.22 & 110.7 & 31.401 \\
\hline Tone & 20-Sep & 7 & $\mathrm{~F}$ & 7.62 & 103.826 & 62.519 & 89.6 & 9.713 \\
\hline Tone & 20-Sep & 8 & $F$ & 7.62 & 102.279 & 76.316 & 96.4 & 7.002 \\
\hline Tone & 05-Oct & 2 & $F$ & 7.62 & 167.332 & 170.023 & 29.1 & 112.11 \\
\hline Tone & 05-Oct & 4 & $F$ & 7.62 & 252.951 & 81.51 & 158.7 & 66.86 \\
\hline Tone & 05-Oct & 5 & $F$ & 8.89 & 143.392 & 91.814 & 123 & 13.525 \\
\hline Tone & 05-Oct & 6 & $F$ & 7.62 & 154.563 & 74.219 & 114.5 & 21.545 \\
\hline Tone & 05-Oct & 7 & $\mathrm{~F}$ & 7.62 & 174.219 & 77.174 & 108.5 & 29.131 \\
\hline Tone & 20-Sep & 4 & M & 7.62 & 136.116 & 90.637 & 117.6 & 11.975 \\
\hline Tone & 20-Sep & 5 & M & 7.62 & 151.442 & 84.511 & 126.4 & 16.04 \\
\hline Tone & 05-Oct & 1 & M & 7.62 & 121.524 & 78.685 & 62.5 & 55.819 \\
\hline Tone & 05-Oct & 3 & M & 10.16 & 247.475 & 62.34 & & 45.613 \\
\hline White Noise & 04-Oct & 1 & $\mathrm{~F}$ & 7.62 & 161.633 & 78.951 & 128.7 & 30.082 \\
\hline White Noise & 04-Oct & 3 & $F$ & 7.62 & 142.385 & 80.759 & 5.3 & 18.738 \\
\hline White Noise & 04-Oct & 4 & $F$ & 7.62 & 130.765 & 80.719 & 108.5 & 15.576 \\
\hline White Noise & 04-Oct & 7 & $\mathrm{~F}$ & 7.62 & 174.492 & 111.961 & 135.2 & 13.418 \\
\hline White Noise & 04-Oct & 8 & $F$ & 7.62 & 109.481 & 0.239 & 69.4 & 34.928 \\
\hline White Noise & 23-Oct & 1 & $F$ & 7.62 & 93.783 & 110.447 & 71.3 & 30.221 \\
\hline White Noise & 23-Oct & 2 & $F$ & 7.62 & 23.12 & 126.355 & 80.8 & 23.401 \\
\hline White Noise & 23-Oct & 5 & $F$ & 6.35 & 38.926 & 198.18 & 137.9 & 42.66 \\
\hline White Noise & 04-Oct & 2 & M & 7.62 & 165.84 & 82.271 & 113 & 26.597 \\
\hline White Noise & 04-Oct & 5 & $M$ & 10.16 & 122.094 & 90.332 & 112.8 & 10.305 \\
\hline White Noise & 04-Oct & 6 & $M$ & 8.89 & 141.506 & 73.575 & 96.6 & 17.741 \\
\hline White Noise & 04-Oct & 9 & $M$ & 10.16 & 129.07 & 87.45 & 108.6 & 9.533 \\
\hline White Noise & & 3 & $M$ & 11.43 & 83.827 & 180.685 & 134.4 & 33.11 \\
\hline White Noise & 23-Oct & 4 & $M$ & 7.62 & 91.363 & 32.205 & 34.1 & 47.739 \\
\hline
\end{tabular}


Appendix F: Experimental tank acoustics. Sound travels from the left side (speaker) to the right side (net).

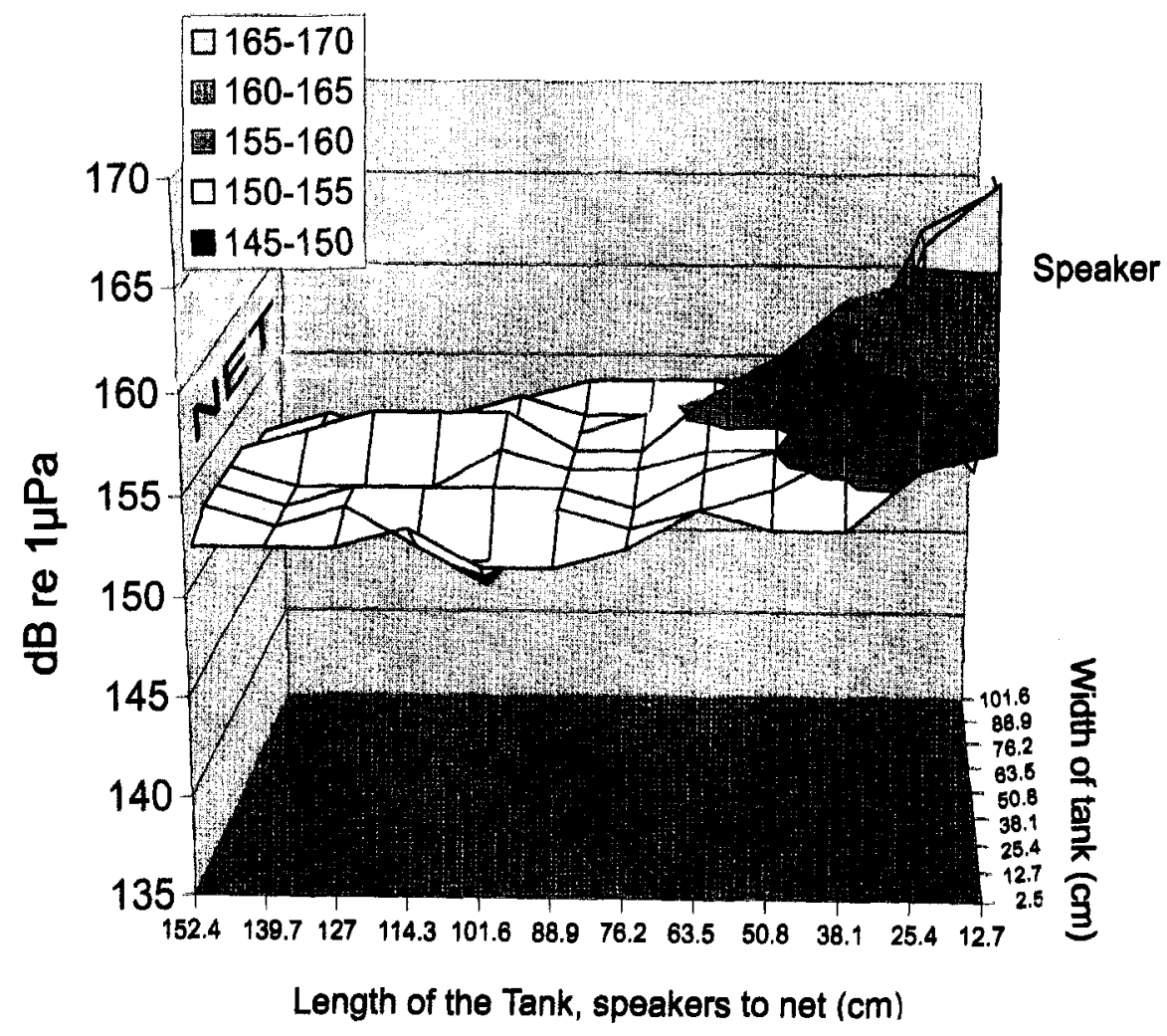




\section{Literature Cited}

Adreani, M.S., Erisman, B.E., Warner, R.R. (2004) Courtship and spawning behavior in the California sheephead, Semicossyphus pulcher (Pisces : Labridae). Environmental Biology of Fishes 71 (1): 13-19.

Amorim, M.C.P., Stratoudakis, Y., Hawkins, A.D. (2004) Sound production during competitive feeding in the grey gurnard. Journal of Fish Biology 65 (1): 182-194.

Au, W.W.L., Banks, K. (1998) The acoustics of the snapping shrimp Synalpheus parneomeris in Kaneohe Bay. Journal of the Acoustical Society of America 103 (1): $41-47$.

Best, A.C.G., Gray, J.A.B. (1980) Morphology of the utricular recess in the sprat. Journal of Marine Biological Association of the UK 60,703 -715.

Bisazza, A., Manfredi, S., Pilastro, A. (2000) Sexual competition, coercive mating and mate assessment in the one-sided livebearer, Jenynsia multidentata: Are they predictive of sexual dimorphism? Ethology 106 (11): 961-978.

Braun, C.B., Coombs, S. (2000) The overlapping roles of the inner ear and lateral line: the active space of dipole source detection. Philosophical Transactions of the Royal Society of London Series [B] 355 (1401): 1115-1119.

Cameron, E.Z., Linklater, W.L., Stafford, K.J., Minot, E.O. (2003) Social grouping and maternal behaviour in feral horses (Equus caballus): the influence of males on maternal protectiveness. Behavioral Ecology and Sociobiology 53 (2): 92-101.

Chardon, M., Vandewalle, P. (1997) Evolutionary trends and possible origin of the Weberian apparatus. Netherlands Journal of Zoology 47:383-403.

Charlebois, P.M., Marsden, J.E., Goettell, R.G., Wolfe, R.K., Jude, D.J., Rudnika, S. (1997) The round goby, Neogobius melanostomus (Pallus), a review of European and North American Literature. Illimois-Indiana Sea Grant Program and Illinois Natural History Survey. Ill. Nat. Hist. Surv. Spec. Publ. No. 20, p. 76.

Coleman; P.D. (1963) An analysis of cues to auditory depth perception in free space. Psychological Bulletin, 60:302-15.

Coombs, S., Hastings, M., Finneran, J. (1995) Modeling and measuring lateral line excitation patterns to changing dipole source locations. Journal of Comparative Physiology [A] 178:359-371.

Coombs, S., Montgomery, J.C. (1999) The enigmatic lateral line system. In: Comparative Hearing: Fish and Amphibians, edited by Fay RR, and Popper AN. New York: Springer-Verlag, p. 319-362. 
Corkum, L.D. (2004) Pheromone signalling in conservation. Aquatic ConservationMarine and Freshwater Ecosystems 14 (4): 327-331.

Corkum, L.D., Sapota, M.R., Skora, K.E. (2004) The round goby, Neogobius melanostomus, a fish invader on both sides of the Atlantic Ocean. Biological Invasions 6: 173-181.

Crawford, J.D., Jacob, P., Benech, V. (1997) Sound production and reproductive ecology of strongly acoustic fish in Africa: Pollimyrus isidori, Mormyridae. Behaviour 134: 677-725 Part 9-10.

de Perera, T.B. (2004) Fish can encode order in their spatial map. Proceedings of the Royal Society of London Series B-Biological Sciences 271 (1553): 2131-2134.

de Vries, H.L. (1950) The mechanics of the labyrinth otoliths. Acta Otolaryngol 38:262-273

Demski, L.S., Gerald, J.W., Popper, A.N. (1973) Central and peripheral mechanisms of teleost sound production. American Zoologist 13: 1141-1167.

Denton, E.J. and Gray, J.A.B. (1979) The analysis of sound by the sprat ear. Nature $282,406-407$.

Denton, E.J., Gray, J.A.B. (1982) The rigidity of fish and patterns of lateral line stimulation. Nature 297:679-681.

Dijkgraaf, S. (1962) The functioning and significance of the lateral-line organ. Biological Review 38, 51-105.

Dubs, D.O.L., Corkum, L.D. (1996) Behavioral Interactions Between Round Gobies (Neogobius melanostomus) and Mottled Sculpins (Cottus bairdi). Journal of Great Lakes Research 22(4): 838-844.

Fay, R.R. (1984) The goldfish ear codes the axis of particle motion in three dimensions. Science 225:951-953

Fay, R.R. (1988) Hearing in vertebrates: a psychophysics databook. Hill-Fay Associates, Winetka, Illinois.

Fay, R.R. (1995) Physiology of primary saccular afferents of goldfish - implications for mauthner cell response. Brain Behavior and Evolution 46 (3): 141-150.

Fay, R.R., Feng A.S. (1987) Directional hearing among nonmammalian vertebrates. In W.A. Yost and G. Gourevitch (Eds.), Directional Hearing, Springer-Verlag, New York, pp. 179-213. 
Finstad, J.L., Nordeide, J.T. (2004) Acoustic repertoire of spawning cod, Gadus morhua. Environmental Biology of Fishes 70 (4): 427-433.

Gerald, J.W. (1971). Sound production in six species of sunfish (Centrarchidae). Evolution 25, 75-87.

Hancock, K.E., Delgutte, B. (2004) A physiologically based model of interaural time difference discrimination. Journal of Neuroscience 24 (32): 7110-7117.

Harris, J.A., Cheng, A.G., Cunningham, L.L., MacDonald, G., Raible, D.W., Rubel, E.W. (2003) Neomycin-induced hair cell death and rapid regeneration in the lateral line of zebrafish (Danio rerio). Journal of the Association for Research in Otolaryngology 4 (2): 219-234.

Hawkins, A.D., Amorim, M.C.P. (2000) Spawning sounds of the male haddock, Melanogrammus aeglefinus. Environmental Biology of Fishes 59 (1): 29-41.

Henglmuller, S.M., Ladich, F. (1999) Development of agonistic behaviour and vocalization in croaking gouramis. Journal of Fish Biology 54 (2): 380-395.

Heyd, A., Pfeiffer, W. (2000) Sound production in catfish (Siluroidei, Ostariophysi, Teleostei) and its relationship to phylogeny and fright reaction. Revue Suisse De Zoologie 107 (1): 165-211.

Higgs, D.M., Plachta, D.T.T., Rollo, A.K., Singheiser, M., Hastings, M.C., Popper, A.N. (2004) Development of ultrasound detection in American shad (Alosa sapidissima). Journal of Experimental Biology 207 (1): 155-163.

Higgs, D.M., Rollo, A.K., Souza, M.J., Popper, A.N. (2003) Development of form and function in peripheral auditory structures of the zebrafish (Danio rerio). Journal of the Acoustical Society of America 113 (2): 1145-1154.

Hudspeth, A.J., Corey, D.P. (1977) Sensitivity, Polarity, and Conductance Change in Response of Vertebrate Hair Cells to Controlled Mechanical Stimuli. Proceedings of the National Academy of Sciences of the USA 74 (6): 2407-2411

Johnson, D.L. (2000) Sound production in Cyprinodon bifasciatus

(Cyprinodontiformes) Environmental Biology of Fishes 59 (3): 341-346.

Johnston, C.E., Johnson, D.L. (2000) Sound production during the spawning season in cavity-nesting darters of the subgenus Catonotus (Percidae: Etheostoma). COPEIA (2): 475-481.

Jude, D. J., DeBoe, S. (1996) Possible impact of gobies and other introduced species on habitat restoration efforts. Canadian Journal of Fisheries and Aquatic Sciences 53 (Suppl. 1):136-141. 
Kenyon, T.N. (1984) The significance of sound interception to males of the bicolor damselflish, Pomacentrus partitus, during courtship. Environmental Biology of Fishes 40 (4): 391-405.

Kenyon, T.N., Ladich, F., Yan, H.Y. (1998) A comparative study of hearing ability in fishes: the auditory brainstem response approach. Journal of Comparative Physiology A-Sensory Neural and Behavioral Physiology 182 (3): 307-318.

Kottelat, M. (1997) European freshwater fishes. Biologia 52, Supplement 5:178-179.

Ladich, F. (1997). Agonistic behavior and significance of sounds. Marine and Freshwater Behavior Physiology 29, 87-108.

Ladich, F. (1998) Sound characteristics and outcome of contests in male croaking gouramis (Teleostei). Ethology 104 (6): 517-529.

Lindström, K. (1992) Female spawning patterns and male mating success in the sand goby Pomatoschistus minutes. Marine Biology 113 (3): 475-480.

Lindström, K., Lugli, M. (2000) A quantitative analysis of the courtship acoustic behaviour and sound patterning in male sand goby, Pomatoschistus minutes. Environmental Biology of Fishes 58 (4): 411-424.

Lobel, P.S. (1992) Sound produced by spawning fishes. Environmental Biology of Fishes. 33:351-358.

Lobel, P.S. (2001) Acoustic behavior of cichlid fishes. Journal of Aquariculture Aquatic Sciences. 9:167-186.

Lugli, A., Pavan, G., Torricelli, P. (2004) The response of the male freshwater goby to natural and synthetic male courtship sound playback following exposure to different female sexual sitimuli. Ethology Ecology and Evolution 16 (1): 55-70.

Lugli, M., Pavan, G., Torricelli, P., Bobbio, L. (1995) Spawning vocalizations in male freshwater gobiids (Pisces, Gobiidae). Environmental Biology of Fishes 43: 219-231.

Lu, Z., Fay, R.R. (1996) Two-tone interaction in auditory nerve fibers and midbrain neurons of the goldfish, Carassius auratus. Auditory Neuroscience 2:257-273.

Lu, Z., Popper, A.N. (1997) Encoding of acoustic particle motion by saccular ganglion cells of a fish: Intracellular recording and tracing. Soc Neuroscience Abstract 23:180. 
Lu, Z., Popper, A.N., Fay, R.R. (1996) Behavioral detection of acoustic particle motion by a teleost fish (Astronotus ocellatus): sensitivity and directionality. Journal of Comparative Physiology [A] 179 pp. 227-233.

Lu, Z., Xu, Z. (2002) Effects of saccular otolith removal on hearing sensitivity of the sleeper goby (Dormitator latifrons). Journal of Comparative Physiology [A] 188 (8): 595-602.

Lu, Z., Xu, Z., Buchser, W.Z. (2004) Coding of acoustic particle motion by utricular fibers in the sleeper goby, Dormitator latifrons. Journal of Comparative Physiology [A] 190 (11) 923-938.

Malavasi, S., Torricelli, P., Lugli, M., Pranovi, F., Mainardi, D. (2003) Male courtship sounds in a teleost with alternative reproductive tactics, the grass goby, Zosterisessor ophiocephalus. Environmental Biology of Fishes 66 (3): 231-236.

Mann, D.A., Lu, Z., Popper, A.N. (1997) Ultrasound detection by a teleost fish. Nature 389:341.

McKibben, J. Bass, A. (1998) Behavioral assessment of acoustic parameters relevant to signal recognition and preference in a vocal fish. Journal of the Acoustical Society of America 104 (6): 3520-3533.

Miller, P.J. (1984) Tokology of gobies. G.W. Potts and R.J. Wootton, eds. Fish reproduction. Academic Press, Ltd., London. Pp. 119-153.

Morrison, H.A., Whittle, D.M., Haffner, G.D. (2000) The relative importance of species invasions and sediment disturbance in regulating chemical dynamics in western Lake Erie. Ecological Modelling 125: 279-294.

Murphy, C.A., Stacey, N.E. (2002) Methyl-Testosterone Induces Male-Typical Ventilatory Behavior in Response to Putative Steroidal Pheromones in Female Round Gobies (Neogobius melanostomus). Hormones and Behavior 42: 109-115.

Myrberg, A.A. (1997) Sound production by a coral reef fish (Pomacentrus partitus): Evidence for a vocal, territorial "keep-out" signal. Bulletin of Marine Science 60 (3): 1017-1025.

Myrberg, A. A., Jr, Mohler, M. and Catala, J. D. (1986) Sound production by males of a coral reef fish (Pomacentrus partitus): its significance to females. Animal Behavior 34, 913-923.

New, J.G., Fewkes, L.A., Khan, A.N. (2001) Strike feeding behaviour in the muskellunge, Esox masquinongy: contributions of the lateral line and visual sensory systems. Journal of Experimental Biology 204:1207-1221. 
Oswald, J.P., Klug, A., Park, T.J. (1999) Interaural intensity difference processing in auditory midbrain neurons: Effects of a transient early inhibitory input. Journal of Neuroscience 19 (3): 1149-1163.

Popper, A.N. (1977) A scanning electron microscopic study of the sacculus and lagena in the ears of fifteen species of teleost fishes. Journal of Morphology 153:397418.

Popper, A.N., Coombs, S. (1982) The morphology and evolution of the ear in Actinopterygian fishes. American Zoologist 22:311-328.

Popper, A.N., Fay, R.R. The auditory periphery in fishes. In: R.R. Fay and A.N. Popper, Editors, Comparative Hearing: Fish and Amphibians, Springer-Verlag, New York, Berlin, Heidelberg (1999), pp. 43-100.

Popper, A.N., Platt, C. (1993) Inner ear and lateral line. In The physiology of fishes. Edited by D.H. Evans. CRC Press, Boca Raton, Fla. pp. 99-136.

Popper, A.N., Tavolga, W.N. (1981) Structure and function of the ear of the marine catfish, Arius felis. Journal of Comparative Physiology 144:27-34.

Protasov, V.I, Tzvetkov, V.I., Rashchperin, V.K. (1965) Acoustic signalization of round goby (Neogobius melanostomus) from the Azov Sea. Journal of General Biology 26, 2:151-160.

Prum, R.O. (1998) Sexual selection and the evolution of mechanical sound production in Manakins (Aves : Pipridae). Animal Behavior 55: 977-994.

Pumphrey, R.J. (1950) Hearing. Symp. Soc. Experimental Biology 4, 3-18.

Ramcharitar, J.U., Deng, X.H., Ketten, D., Popper, A.N. (2004) Form and function in the unique inner ear of a teleost: The silver perch (Bairdiella chrysoura). Journal of Comparative Neurology 475 (4): 531-539.

Ripley, J.L., Lobel, P.S. (2004) Correlation of acoustic and visual signals in the cichlid fish, Tramitichromis intermedius. Environmental Biology of Fishes 71 (4): 389-394.

Robertson, D. R., Warner, R.R. (1978) Sexual patterns in the labroid fishes of the western Caribbean. II. The parrotfishes (Scaridae). Smithsonian Contributions to Zoology 255:1-26.

Rogers, P.H., Cox, M. (1988) Underwater Sound as a Biological Stimulus. In Sensory Biology of Aquatic Animals, Atema, J., Fay, R.R., Popper, A.N., Tavolga, W.N. (ed.) New York: Springer-Verlag. p. 134. 
Rowe, S., Hutchings, J.A. (2004) The function of sound production by Atlantic cod as inferred from patterns of variation in drumming muscle mass. Canadian Journal of Zoology-Revue 82 (9): 1391-1398.

Sabin, A.T., Macpherson, E.A., Middlebrooks, J.C. (2005) Human sound localization at near-threshold levels. Hearing Research 199 (1-2): 124-134.

Saucier, M.H., Baltz, D.M. (1993) Spawning site selection'by spotted seatrout, Cynoscion nebulosus, and black drum, Pogonias cromis, in Louisiana. Environmental Biology of Fishes 36:257-272.

Schellart, N.A.M., Popper, A.N. (1992) Functional aspects of the evolution of the auditory system of actinopterygian fish. In: Webster DB, Popper AN, Fay RR (eds) The Evolutionary Biology of Hearing. New York: Springer-Verlag, pp. 295-321.

Schellart, N.A.M., Wubbles, R.J. (1998) The Auditory and Mechanosensory Lateral Line System. In: Evans, H. D. (eds) The Physiology of Fishes, Second Edition. CRC Press, New York. Pp. 283-312.

Schleich, P., Nopp, P., D'Haese, P. (2004) Head shadow, squelch, and summation effects in bilateral users of the MED-EL COMBI 40/40+cochlear implant. Ear and Hearing 25 (3): 197-204.

Schuijf, A. (1975) Directional hearing of cod (Gadus morhua) under approximate free field conditions. Journal of Comparative Physiology [A] 98:307-332.

Smith, M.E., Kane, A.S., Popper, A.N. (2004) Acoustical stress and hearing sensitivity in fishes: does the linear threshold shift hypothesis hold water? Journal of Experimental Biology 207 (20): 3591-3602.

Stammler, K.L., Corkum, L.D. (2005) Assessment of fish size on shelter choice and intraspecific interactions by round gobies Neogobius melanostomus. Environmental Biology of Fishes 73:117-123.

Stipetic, E. (1939) Over the endorgan (*Gehororgan) of Mormyriden. Z Vergl Physiology 26:740-752.

Tavolga, W.N. (1956) Visual, chemical and sound stimuli as cues in the sex discriminatory behavior of the gobiid fish, Bathygobius soporator. Zoologica 41:4964.

Tolimieri, N., Jeffs, A., Montgomery, J. (2000) Ambient sound as a cue for navigation in reef fish larvae. Marine Ecology Progress Series 207:219-224.

van Bergeijk, W.A. (1967) The evolution of vertebrate hearing. In: Contribution to Sensory Physiology Volume 2. Neff, W.D. (ed.). pp. 1-49. Berlin: Springer-Verlag. 
Vanderploeg, H.A., Nalepa, T.F., Jude, D.J., Mills, E.L., Holeck, K.T., Liebig, J.R., Grigorovich, I.A., Ojaveer, H. (2002) Dispersal and emerging ecological impacts of Ponto-Caspian species in the Laurentian Great Lakes. Canadian Journal of Fisheries and Aquatic Sciences 59 (7): 1209-1228.

von Frisch, K. (1938) The sense of hearing in fish. Nature 141, 8-11.

Ware, D.M. (1978) Bioenergetics of pelagic fish: theoretical changes in swimming speed and ration with body size. Journal of the Fisheries Research Board of Canada $35,220-228$.

Williams, I.V., Brett, J.R. (1987) Critical swimming speed of Fraser and Thompson River pink salmon (Oncorhynchus gorbuscha). Canadian Journal of Fisheries and Aquatic Sciences 44, 348-456.

Willis, M.A., Baker, T.C. (1994) Behavior of flying oriental fruit moth males during approach to sex-pheromone sources. Physiological Entomology 19 (1): 61-69.

Wubbles, R.J., Kroese, A.B.A., Schellart, N.A.M. (1993) Response properties of the lateral line and auditory unites in the medulla oblongata of the rainbow trout (Oncorhynchus mykiss). Journal of Experimental Biology 179:77-92. 


\section{Vita Auctoris}

Name:

Place of Birth:

Date of Birth:

Education:
Audrey Katharina Rollo

Houston, Texas; United States of America

February 9, 1971

1986 - 1989 Kaiserslautern American High School, Germany

1989 - 1990 University of Maryland; Munich, Germany

B.Sc. 1990 - 1995 Texas A\&M University; Galveston Island, Texas

M.Sc. 2003 - 2005 University of Windsor; Windsor, Ontario Canada 